\title{
Sensitivity of water scarcity events to ENSO-driven climate variability at the global scale
}

\author{
T. I. E. Veldkamp ${ }^{1}$, S. Eisner ${ }^{2}$, Y. Wada ${ }^{3,4,5}$, J. C. J. H. Aerts ${ }^{1}$, and P. J. Ward ${ }^{1}$ \\ ${ }^{1}$ Institute for Environmental Studies (IVM), VU Amsterdam, Amsterdam, the Netherlands \\ ${ }^{2}$ Center for Environmental Systems Research, University of Kassel, Kassel, Germany \\ ${ }^{3}$ Center for Climate Systems Research, Columbia University, New York, USA \\ ${ }^{4}$ NASA Goddard Institute for Space Studies, New York, USA \\ ${ }^{5}$ Department of Physical Geography, Utrecht University, Utrecht, the Netherlands \\ Correspondence to: T. I. E. Veldkamp (ted.veldkamp@vu.nl)
}

Received: 6 May 2015 - Published in Hydrol. Earth Syst. Sci. Discuss.: 11 June 2015

Revised: 4 September 2015 - Accepted: 28 September 2015 - Published: 8 October 2015

\begin{abstract}
Globally, freshwater shortage is one of the most dangerous risks for society. Changing hydro-climatic and socioeconomic conditions have aggravated water scarcity over the past decades. A wide range of studies show that water scarcity will intensify in the future, as a result of both increased consumptive water use and, in some regions, climate change. Although it is well-known that El NiñoSouthern Oscillation (ENSO) affects patterns of precipitation and drought at global and regional scales, little attention has yet been paid to the impacts of climate variability on water scarcity conditions, despite its importance for adaptation planning. Therefore, we present the first global-scale sensitivity assessment of water scarcity to ENSO, the most dominant signal of climate variability.

We show that over the time period 1961-2010, both water availability and water scarcity conditions are significantly correlated with ENSO-driven climate variability over a large proportion of the global land area $(>28.1 \%)$; an area inhabited by more than $31.4 \%$ of the global population. We also found, however, that climate variability alone is often not enough to trigger the actual incidence of water scarcity events. The sensitivity of a region to water scarcity events, expressed in terms of land area or population exposed, is determined by both hydro-climatic and socioeconomic conditions. Currently, the population actually impacted by water scarcity events consists of $39.6 \%$ (CTA: consumptionto-availability ratio) and $41.1 \%$ (WCI: water crowding index) of the global population, whilst only $11.4 \%$ (CTA) and $15.9 \%$ (WCI) of the global population is at the same time
\end{abstract}

living in areas sensitive to ENSO-driven climate variability. These results are contrasted, however, by differences in growth rates found under changing socioeconomic conditions, which are relatively high in regions exposed to water scarcity events.

Given the correlations found between ENSO and water availability and scarcity conditions, and the relative developments of water scarcity impacts under changing socioeconomic conditions, we suggest that there is potential for ENSO-based adaptation and risk reduction that could be facilitated by more research on this emerging topic.

\section{Introduction}

Over the past decades, changing hydro-climatic and socioeconomic conditions have led to increased regional and global water scarcity problems (Alcamo et al., 1997; Kummu et al., 2010; van Beek et al., 2011; van Vliet et al., 2013; Veldkamp et al., 2015; Vörösmarty et al., 2000; Wada et al., 2011a). Freshwater shortage is recognized as one of the most dangerous global risks, not only in terms of likelihood but also with respect to its impacts, with societal and economic consequences that result from the inability to meet water demands (Hanemann, 2006; Howell, 2013; Rijsberman, 2006; Young, 2005). In the near future, projected changes in human water use and population growth - in combination with climate change - are expected to aggravate water scarcity conditions and their associated impacts on society (Alcamo et al., 2007; 
Haddeland et al., 2014; Kiguchi et al., 2015; Lehner et al., 2006; Prudhomme et al., 2014; Schewe et al., 2014; Sperna Weiland et al., 2012; Stahl, 2001; van Vliet et al., 2013; Wada et al., 2014a).

Whilst a wide range of studies have assessed the role of long-term climate change and changing socioeconomic conditions on past and future global blue water availability and water scarcity events, the impact of inter-annual climate variability is less well understood (Kummu et al., 2014; Lundqvist and Falkenmark, 2010; Rijsberman, 2006; Veldkamp et al., 2015). Taking into account the impact of climate variability relative to longer term changes in either the socioeconomic or climatic conditions is, however, important as these factors of change may amplify or offset each other at the regional scale (Hulme et al., 1999; McPhaden et al., 2006; Murphy et al., 2010; Veldkamp et al., 2015). Correct information on current and future water scarcity conditions and thorough knowledge of the relative contribution of its driving forces, such as inter-annual variability, help water managers and decisions makers in the design and prioritization of adaptation strategies for coping with water scarcity.

To address this issue, we assess in this paper the sensitivity of blue water resources availability (i.e. the surface fresh water availability in rivers, lakes, wetlands, and reservoirs; Savenije, 2000; Wada et al., 2011b), consumptive water use, and blue water scarcity events to climate variability driven by El Niño-Southern Oscillation (ENSO) at the global scale over the time period 1961-2010. Moreover, we evaluated whether those areas with statistically significant correlations have been exposed to blue water scarcity events, if there is a spatial clustering in terms of population or land area exposed to blue water scarcity events and/or population living in areas sensitive to ENSO-driven climate variability, and whether this spatial clustering has changed over time given the socioeconomic developments. Within this contribution we investigate the impact of ENSO as it is the most dominant signal of inter-annual climate variability (McPhaden et al., 2006). Also, since ENSO can be predictable with reasonable skill up to several seasons in advance (Cheng et al., 2011; Ludescher et al., 2014), this can provide useful information for adaptation management to account for inter-annual variability in blue water resources and blue water scarcity estimates, enabling the prioritization of adaptation efforts in the most affected regions ahead of those extreme events (Bouma et al., 1997; Cheng et al., 2011; Dilley and Heyman, 1995; Ludescher et al., 2013; Ward et al., 2014a, b; Zebiak et al., 2014).

ENSO is the result of a coupled climate variability system in which ocean dynamics and sea level pressure interact with atmospheric convection and winds (ocean-atmosphere feedback mechanisms). El Niño is the oceanic component, whereby waters over the eastern equatorial Pacific Ocean reach anomalously high temperatures. This eastern Pacific Ocean surface is relatively cool under neutral conditions, while it reaches anomalously low temperatures during La
Niña conditions. The Southern Oscillation is the atmospheric component, represented by the east-west shifts in the tropical atmospheric circulation between the Indian and West Pacific oceans and the East Pacific Ocean (Kiladis and Diaz, 1989; Parker et al., 2007; Rosenzweig and Hillel, 2008; Wallace and Hobbs, 2006; Wang et al., 2004). ENSO is wellknown for its impacts on precipitation and hydrological extremes (such as drought and flooding) at local and regional scales (e.g. Chiew et al., 1998; Kiem and Franks, 2001; Lü et al., 2011; Mosley, 2000; Moss et al., 1994; Piechota and Dracup, 1999; Räsänen and Kummu, 2013; Whetton et al., 1990; Zhang et al., 2015). Several studies have also examined ENSO's impact at the global scale (Chiew and McMahon, 2002; Dai and Wigley, 2000; Dettinger et al., 2000; Dettinger and Diaz, 2000; Labat, 2010; Ropelewski and Halpert., 1987; Sheffield et al., 2008; Vicente-Serrano et al., 2011; Ward et al., 2010, 2014a). Though, only a limited number of studies assessed the societal impacts (e.g. in terms of population affected, GDP loss, or with respect to human health) of hydrological extremes under the different ENSO stages at the global scale (Bouma et al., 1997; Dilley and Heyman, 1995; Kovats et al., 2003; Rosenzweig and Hillel, 2008; Ward et al., $2014 \mathrm{~b}$ ). To the best of our knowledge, none of these studies have executed a global-scale assessment of the sensitivity of water resources availability, consumptive water use patterns, and water scarcity events to ENSO.

\section{Methods}

In short, we carried out this assessment through the following steps: (1) used daily discharge and runoff time series $\left(0.5^{\circ} \times 0.5^{\circ}\right)$ from an ensemble of three global hydrological models (WaterGAP, PCR-GLOBWB, and STREAM) (Sect. 2.1); (2) combined time series of water availability, consumptive water use, and population to calculate water scarcity conditions for the period 1961-2010 (Sect. 2.2-2.4); (3) identified statistical relationships between water availability, consumptive water use and water scarcity conditions, and indices of ENSO (Sect. 2.5); and (4) evaluated whether the areas with significant correlations with ENSO are actually affected by water scarcity events, how the impacts (population and land area affected) are clustered, and how the impacts have changed through time (Sect. 2.5). Modelling uncertainty was evaluated by comparing the results from the ensemble-mean time series with the outcomes of the individual global hydrological models (Sect. 2.6). The following paragraphs describe our methods in detail.

\subsection{Ensemble-mean monthly runoff and discharge}

We simulated global gridded daily discharge and runoff over the period 1960-2010 at a resolution of $0.5^{\circ} \times 0.5^{\circ}$ using three global hydrological models: PCR-GLOBWB (van Beek et al., 2011; Wada et al., 2014b), STREAM (Aerts et 
al., 1999; Ward et al., 2007) and WaterGAP (Müller Schmied et al., 2014), forced with WATCH Forcing Data - ERA Interim (WFD-EI) daily precipitation and temperature data $\left(0.5^{\circ} \times 0.5^{\circ}\right)$ (Weedon et al., 2014) for the period 19792010 and WATCH forcing data ERA40 (WFD) for the period 1960-1978 (Weedon et al., 2011). In order to compensate for offsets in long-term radiation fluxes between the two data sets, as found by Müller Schmied et al. (2014), WFD down-welling shortwave and long-wave radiation were adjusted for use in WaterGAP to WFD-EI long-term means following the approach of Haddeland et al. (2012). Daily values were aggregated to time series of monthly discharge and runoff. Using global hydrological models gives us the advantage of a global coverage, whereas the portfolio of observed data sets (water availability and consumptive water use) is bounded by its biased regional distribution (Hannah et al., 2011; Ward et al., 2010, 2014a). However, we are aware of the caveats using these types of models to estimate water availability as all large-scale hydrological models have their own strengths and shortcomings (Gudmundsson et al., 2012; Nazemi and Wheater, 2015a, b). Therefore, we constructed ensemble-mean time series of both monthly discharge and runoff capturing the three global hydrological models. The results of the individual modelling efforts were used to evaluate the modelling agreement (Sects. 2.4 and 3.5).

\subsection{Calculating water availability}

Water availability is expressed in this paper as the sum of monthly runoff per food producing unit (FPU). FPUs represent a hybrid between river basins and economic regions for which it is generally assumed that water scarcity issues can be solved internally (Cai and Rosegrant, 2002; de Fraiture, 2007; Kummu et al., 2010; Rosegrant et al., 2002). We used here an updated version of the FPU used by Kummu et al. (2010), which consists of 436 FPUs, excluding small island FPUs. For FPUs located within one of the world's larger river basins, we redistributed runoff in order to avoid local over- or underestimations in water availability. Runoff was redistributed across the FPUs within these larger river basins, proportionally to the discharge distribution of that large river basin (Gerten et al., 2011; Schewe et al., 2014):

$\mathrm{WA}_{i}=\frac{R_{\mathrm{b}} * Q_{\mathrm{i}}}{\sum Q_{\mathrm{i}}}$,

whereby $\mathrm{WA}_{i}$ is the monthly water availability within FPU $i, R_{\mathrm{b}}$ is the total monthly runoff within large river basin $b, Q_{i}$ is the monthly discharge in FPU $i$, and $\sum Q_{i}$ is the sum of the monthly discharge over all cells within a large river basin $b$.

Subsequently, we calculated the annual water availability by aggregating the simulated ensemble-mean monthly water availability time series using hydrological years. The use of hydrological years is necessary in this assessment, as ENSO tends to develop to its fullest strength during the period December-February, which intersects with the stan- dard calendar year boundaries (Ward et al., 2014a, b). Hydrological years are referred to by the year in which they end, e.g. hydrological year 1961 refers here to the period October 1960-September 1961. Within this study we follow Ward et al. (2014a) and distinguish two hydrological years on the basis of long-term monthly maximum water availability per river basin: October-September (standard) and JulyJune (for river basins that have their long-term monthly maximum water availability in September, October or November). The river basin delineation used here was derived from the WATCH project (Döll and Lehner, 2002) and is equal to the river basin delineation that is used as the input for the FPU classification used within this study. We used the hydrological years setting determined at grid level, using the WATCH river basins, as input for the distinction between hydrological years at FPU scale. If an FPU consisted of more than one river basin we based the choice of hydrological year on the month (with long-term maximum water availability) with the highest prevalence within this FPU (see Supplement Fig. S1).

\subsection{Calculating consumptive water use}

Monthly gridded water consumption $\left(0.5^{\circ} \times 0.5^{\circ}\right)$ was estimated for the sectors livestock, irrigation, industry, and domestic within PCR-GLOBWB using daily WFD-EI precipitation and temperature data in combination with yearly information on livestock densities; the extent of irrigated areas; desalinated water use; non-renewable groundwater abstractions; and past socioeconomic developments, namely GDP, energy and electricity production, household consumption, and population growth (Wada et al., 2011b, 2014b). For a complete description and extensive discussion of the methodological steps taken to compose these monthly consumptive water use time series, we refer to Wada et al. (2011b, 2014b). Time series of desalinated water use and non-renewable groundwater abstractions were subtracted from the total consumptive water use estimates as they lower the need for blue water. Subsequently, we aggregated gridded monthly consumptive water use into yearly totals per FPU $\left(\mathrm{WC}_{i, \mathrm{yr}}\right)$, following the hydrological years. Since the resulting transient consumptive water use estimates are partially driven by changing socioeconomic conditions (population, GDP, and growth in irrigated areas), and therefore disguise any possible correlations with ENSO-driven climate variability; we repeated the steps above whilst we fixed the socioeconomic parameters at 1961 levels (following the hydrological year naming convention). These fixed consumptive water use estimates were used to evaluate the sensitivity to ENSO-driven climate variability (Sects. 3.1 and 3.2), whereas the transient water consumption time series were used to evaluate the development of water scarcity conditions under changing socioeconomic conditions (Sect. 3.3). 


\subsection{Calculating water scarcity conditions}

Blue water scarcity refers to the imbalance between blue water availability (i.e. water in rivers, lakes, and aquifers) and the needs for water over a specific time period and for a certain region (Falkenmark, 2013). Although water scarcity could also relate to the green (water in the unsaturated soil), white (part of rainfall that feeds directly back into the atmosphere), and deep blue (fossil groundwater) water sources (Savenije, 2000), we focus here on blue water scarcity (hereafter: water scarcity) only. Within this study we applied two complementary indicators to express water scarcity conditions per FPU: the water crowding index (WCI) for population-driven water shortage and the consumption-toavailability ratio (CTA ratio) for demand-driven water stress (Brown and Matlock, 2011; Rijsberman, 2006). The WCI quantifies the yearly water availability per capita (Falkenmark et al., 1989, 2007; Falkemark, 2013), whereby water demands are based on household, agricultural, industrial, energy, and environmental water consumption (Rijsberman, 2006). Like previous studies (e.g. Alcamo et al., 2007; Arnell, 2003; Kummu et al., 2010), we used $1700 \mathrm{~m}^{3}$ capita $^{-1}$ per year as the threshold level to evaluate water shortage events. The CTA ratio evaluates the ratio between consumptive water used and water availability in a specific region and is a derivative from the withdrawal-to-availability (WTA; Raskin et al., 1997) ratio. Usually, a region is said to experience water stress events when water withdrawals comprises $\geq 40 \%$ of the available water resources, whilst moderate water stress conditions occur if $20 \% \geq \mathrm{WTA} \leq 40 \%$ (Raskin et al., 1997). The use of the WTA ratio is widely quoted and applied in previous research contributions, e.g. by Alcamo et al. (2003, 2007), Arnell et al. (1999), Cosgrove and Rijsberman (2000), Hanasaki et al. (2013), Kiguchi et al. (2015), Kundzewicz et al. (2007), Oki et al. (2001), Oki and Kanae (2006), and Vörösmarty et al. (2000). Hoekstra et al. (2012) and Wada et al. (2011a) applied this WTA ratio in an adapted form, using blue water footprints and potential consumptive water use estimates respectively to assess water stress conditions: the CTA ratio. This approach accounts for the share of water that has been recycled (industry) or not used (irrigation) and which flows back into the natural system. The threshold level for water stress using these consumptive water demands is therefore conceived to be lower than the threshold level for water stress as estimated using withdrawals. Following Hoekstra et al. (2011, 2012), Richter et al. (2011), and Wada et al. (2011a), we applied a threshold level of 0.2 to indicate water stress events. Equations (2) and (3) show the use of the $\mathrm{WCI}\left(\mathrm{WCI}_{i, \mathrm{yr}}\right)$ and the CTA ratio $\left(\mathrm{CTA}_{i, \mathrm{yr}}\right)$, respectively,

$\mathrm{WCI}_{i, \mathrm{yr}}=\frac{\mathrm{WA}_{i, \mathrm{yr}}}{P_{i, \mathrm{yr}}}\left(\right.$ water shortage event if $\left.\mathrm{WCI}_{i, \mathrm{yr}} \leq 1700\right)$,
$\mathrm{CTA}_{i, \mathrm{yr}}=\frac{\mathrm{WC}_{i, \mathrm{yr}}}{\mathrm{WA}_{i, \mathrm{yr}}}$ (water stress event if $\mathrm{CTA}_{i, \mathrm{yr}} \geq 0.2$ ),

whereby $\mathrm{WA}_{i, \mathrm{yr}}$ is the water available per spatial unit $i$ and hydrological year yr, $P_{i, \mathrm{yr}}$ is the population, and $\mathrm{WC}_{i, \mathrm{yr}}$ is consumptive water use. Water scarcity conditions were assessed here at the FPU scale. The FPU scale is seen as an appropriate spatial scale to study water scarcity conditions as it is generally assumed that lower-scale water scarcity issues can be overcome by the reallocation of water demand and supply within this spatial unit (Kummu et al., 2010). However, one should keep in mind that, due to the assumption of full exchange possibilities - both from an infrastructural and water management perspective and its relative large spatial scale, analysis executed at the FPU scale may disguise lower-scale water scarcity issues (Kummu et al., 2010; Wada et al., 2011a).

The population data used for the calculation of the WCI (Eq. 2) were adopted from Wada et al. (2011a, b), who derived yearly gridded population maps $\left(0.5^{\circ} \times 0.5^{\circ}\right)$ from yearly country-scale FAOSTAT data in combination with decadal gridded global population maps (Klein Goldewijk and van Drecht, 2006). We aggregated these gridded population maps to FPU scale for use in this study. In line with the hydrological year naming convention, population estimates were used for the year in which the hydrological year ends; e.g. for hydrological year 1961 we used population estimates of 1961 as input for the WCI and to calculate water scarcity impacts.

\subsection{Sensitivity of water availability, consumptive water use, and water scarcity conditions to ENSO}

We examined the relationship respectively between water availability, consumptive water use, and water scarcity conditions, and ENSO-driven climate variability by means of their correlation with the Japan Meteorological Agency's (JMA) Sea Surface Temperature (SST) anomaly index (http://coaps. fsu.edu/jma). We used here 3-monthly mean values of the JMA SST over the periods October-December, NovemberJanuary, December-February, and January-March, as El Niño and La Niña expressions are strongest in these months (Dettinger and Diaz, 2000). Following Ward et al. (2014b), we examined the correlation between $\mathrm{WA}_{\mathrm{ann}}$, $\mathrm{WC}_{\mathrm{ann}}, \mathrm{CTA}_{\mathrm{ann}}$, and $\mathrm{WCI}_{\mathrm{ann}}$, and the 3-monthly mean JMA SST values (OND, NDJ, DJF, JFM), using Spearman's rank correlation coefficient. Statistical significance was assessed by means of regular bootstrapping $(n=1000, p \leq 0.05)$ while field significance, i.e. the joint statistical significance of multiple individual significance tests (Livezey and Chen, 1982; Wilks, 2006), for each of the 3-monthly JMA SST correlation values was tested using the binomial distribution (Livezey and Chen, 1982). With field significance testing, we 
counted the number of individual tests with a significant result and assessed the probability of yielding this result by chance given its statistical distribution (Livezey and Chen, 1982; Wilks, 2006). Subsequently, we examined the percentage anomalies in the median values of water scarcity conditions between El Niño and La Niña years, compared to the median values under all years. To distinguish between El Niño, La Niña, and neutral years we used the classification of ENSO years from the Center for Ocean-Atmospheric Prediction Studies based on the JMA SST values. Years are assigned as El Niño or La Niña years when their 5-month moving average JMA SST index values are $( \pm) 0.5^{\circ} \mathrm{C}$ or greater (El Niño)/smaller (La Niña) for at least 6 consecutive months (including October-December). Reference to the different ENSO years was adjusted to be consistent with the naming convention used for the hydrological years (Table 1). We used a bootstrapped version of the non-parametric Mann-Whitney $U$ test $(n=1000, p \leq 0.05)$ to test the statistical differences in median values.

The critical threshold values put in place for the WCI and the CTA ratio (here 1700 and 0.2 respectively) determine whether water scarcity conditions adversely affect population or society. Per FPU we therefore evaluated which proportion of land area, for which we found a significant correlation between ENSO and water scarcity conditions, is also exposed to water scarcity events and how population is clustered in these areas compared to the general pattern of population density. Moreover, we assessed how these numbers changed through time given the changing socioeconomic conditions, relative to developments in (1) the population and land area sensitive to ENSO-driven climate variability but not exposed to water scarcity events; (2) the population and land area exposed to water scarcity events in areas that lack a significant correlation with ENSO-driven climate variability; and to (3) the total population growth.

\subsection{Evaluating modelling uncertainty}

A cross-model validation was executed in order to evaluate the modelling uncertainty whereby we compared the results from the ensemble mean with the outcomes of the individual global hydrological models (GHM). We examined the agreement among the different modelling results and the ensemble mean when looking at (1) the sensitivity of water availability and water scarcity conditions to ENSO-driven climate variability, and (2) the impacts of water scarcity events and relation to ENSO-driven climate variability under changing socioeconomic conditions.

\section{Results}

\subsection{Sensitivity of water availability and consumptive water use to ENSO}

Significant correlations of water availability to variations in JMA SST were found across $37.1 \%$ of the global land surface (excluding Greenland and Antarctica), whilst for consumptive water use (simulated under fixed socioeconomic conditions at 1961 levels) we found significant correlations covering $8.3 \%$ of the total land area (Fig. 1 and Table 2). Using the 3-monthly JMA SST period with the highest correlation, Fig. 1 shows for both water availability and consumptive water use its correlation coefficient with the interannual variation in the 3-monthly average JMA SST values. Only those correlations which reach statistical significance at a $95 \%$ confidence interval are shown here. Field significance, the collective global significance of the total of individual local hypothesis tests (Livezey and Chen, 1982; Wilks, 2006), was tested for the individual 3-month correlation results and found to be highly significant when looking at water availability $(p<0.01)$ but insignificant when considering consumptive water use $(p>0.5)$. Positive correlations, i.e. more water available with the JMA SST index moving towards El Niño values, were found for $13.2 \%$ of the global land surface, while negative correlations were found in FPUs covering $23.9 \%$ of the global land surface. When looking at consumptive water use we found positive significant correlations for only $1.0 \%$, and negative correlations for $7.3 \%$ of the global land surface.

\subsection{Sensitivity of water scarcity conditions to ENSO}

Subsequently, we assessed how sensitive water scarcity conditions (simulated under fixed socioeconomic conditions at 1961 levels) are to ENSO-driven climate variability. Significant correlations to variations in JMA SST were found for 28.1 and $37.9 \%$ of the global land surface when using the CTA ratio (water stress) and WCI (water shortage) respectively, while being tested under a $95 \%$ confidence interval (Table 3). Due to the clustering of population and consumptive water use we found even higher percentages when looking at the population living in these areas, 31.4 and $38.7 \%$ of the global population in 2010 for the CTA ratio and WCI, respectively.

Figure 2 shows the areas with a significant positive (red) or negative (blue) correlation of water stress conditions (CTA ratio) with the variation in JMA SST values, using the 3monthly JMA SST period with the highest correlation (JMA $\left.\mathrm{SST}_{\text {bestoff }}\right)$. Correlation results found for water shortage conditions, as defined by the WCI, show a similar pattern as for water stress and are given in Fig. S2 (Supplement). For both metrics, we found that, for a majority of the land area with a significant correlation to ENSO-driven climate variability, 
Table 1. Hydrological years that fall under the El Niño and La Niña phase. Other years are classified as ENSO neutral.

\begin{tabular}{ll}
\hline ENSO phase & Hydrological year \\
\hline El Niño & $1964,1966,1970,1973,1977,1983,1987,1988,1992,1998,2003,2007,2010$ \\
La Niña & $1965,1968,1971,1972,1974,1975,1976,1989,1999,2000,2008$ \\
\hline
\end{tabular}

(a) Water availability

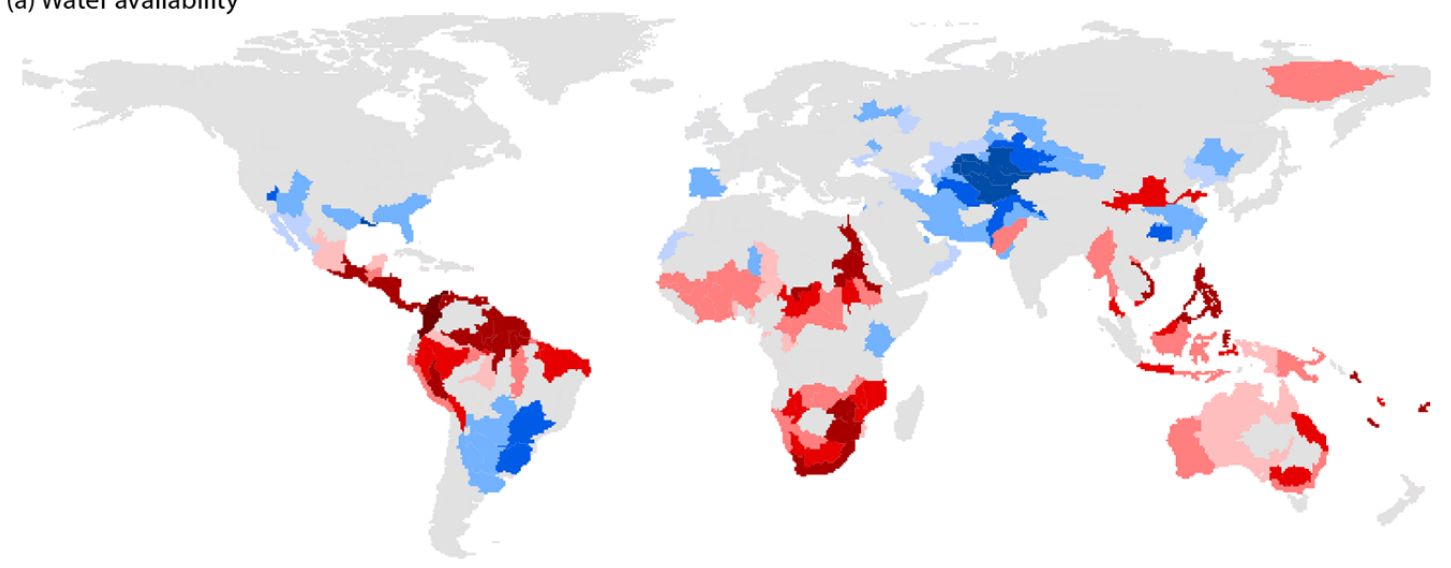

(b) Consumptive water use

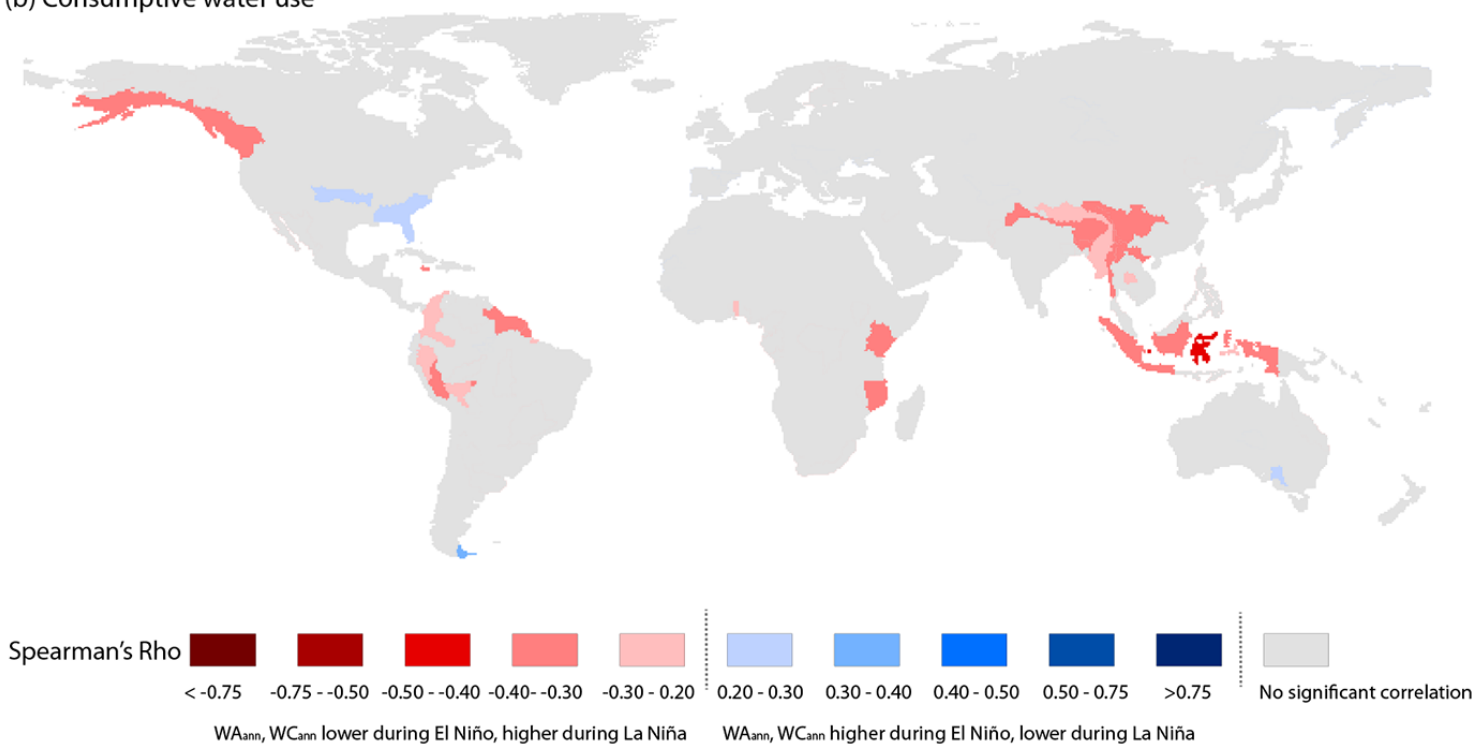

Figure 1. Correlation (Spearman's Rho) of yearly (a) water availability and (b) consumptive water use values, as assessed under fixed

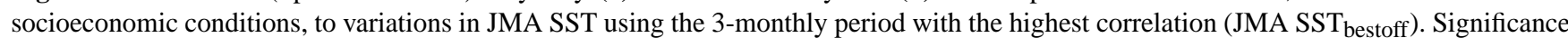
was tested by means of regular bootstrapping $(n=1000, p \leq 0.05)$ and the correlation is only shown for those areas which reach significance.

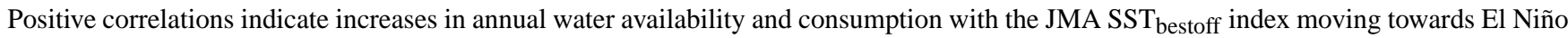
values. Negative correlations indicate decreases in annual water availability with the JMA SST bestoff index moving towards El Niño values.

water scarcity conditions become more severe when the JMA SST index moves towards El Niño values (Table 3).

The regional variation in sensitivity of water scarcity conditions to ENSO-driven variability (Figs. 2 and S2) is clearly driven by the spatial distribution of water availability correlations as the general patterns are similar to those found in Fig. 1. The unequal clustering of water availability and consumptive water use leads, however, in some regions to a strengthening or weakening of the correlation signal, for example when comparing the regional variation in sensitivity results for water stress within the Amazon basin or in Southern Africa (Fig. 2) with the regional variation in correlation results for water availability in those areas (Fig. 1). For a selection of FPUs, we found significant correlations for both 


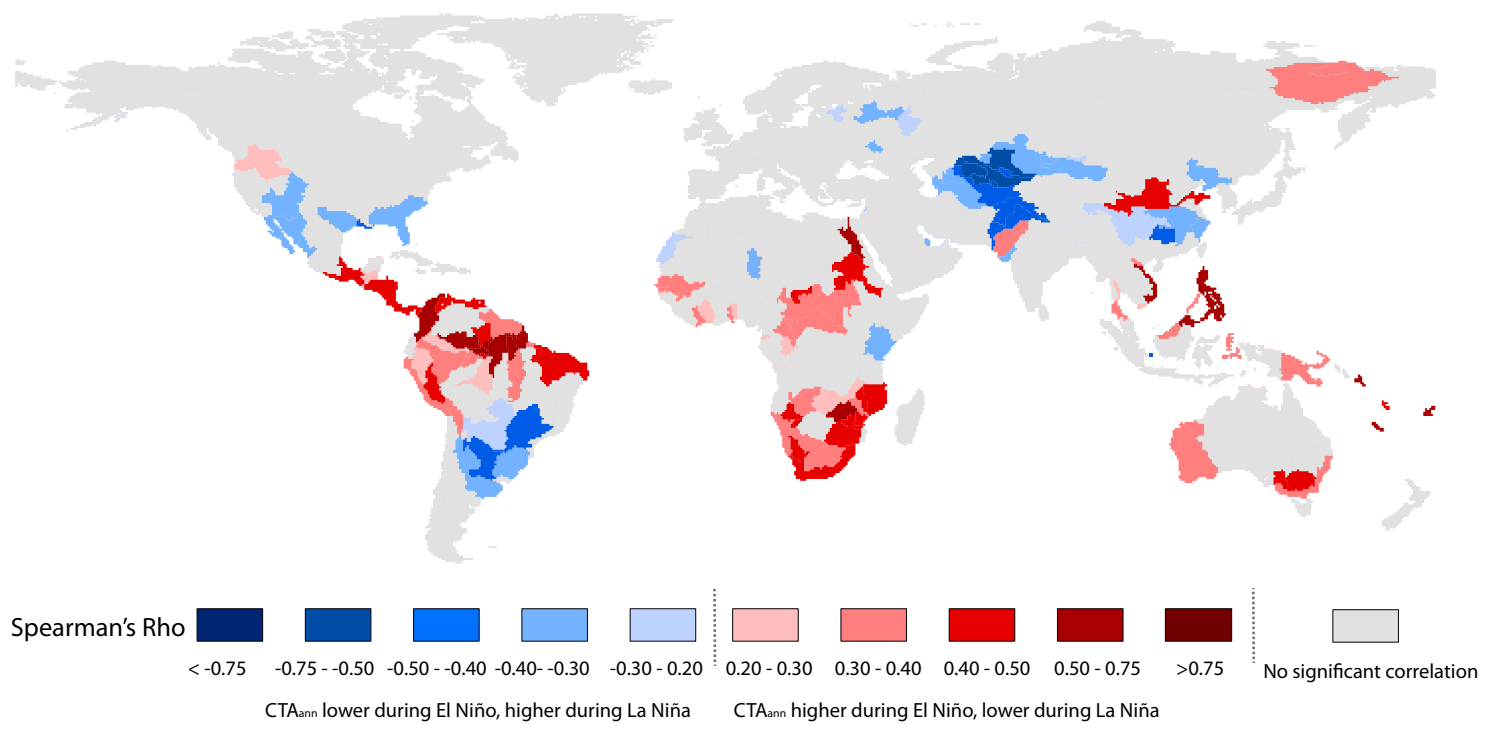

Figure 2. Correlation (Spearman's Rho) of yearly water scarcity conditions (CTA ratio), as assessed under fixed socioeconomic conditions,

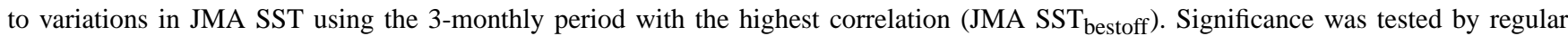
bootstrapping $(n=1000, p \leq 0.05)$ and the correlation is only shown for those areas with significant correlations. Positive correlations indicate increases in CTA-ratio values (more severe water scarcity conditions) with the JMA SST bestoff index moving towards El Niño

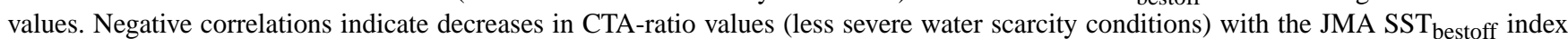
moving towards El Niño values.

Table 2. Percentage of the global land area for which (a) water resources availability and (b) consumptive water use show a significant (positive/negative) correlation with ENSO-driven climate variability (as assessed with the JMA SST anomaly index).

\begin{tabular}{llll}
\hline & $\begin{array}{l}\text { Significant } \\
\text { correlation }\end{array}$ & $\begin{array}{l}\text { Sign. positive } \\
\text { correlation }\end{array}$ & $\begin{array}{l}\text { Sign. negative } \\
\text { correlation }\end{array}$ \\
\hline Water availability & $37.1 \%$ & $13.2 \%$ & $23.9 \%$ \\
Consumptive water use & $8.3 \%$ & $1.0 \%$ & $7.3 \%$ \\
\hline
\end{tabular}

Table 3. Percentage of the global land area for which water scarcity conditions show a significant (positive/negative) correlation with ENSO-driven climate variability (as assessed with the JMA SST anomaly index). Water scarcity conditions were assessed by means of the CTA ratio for water stress and WCI ratio for water shortage.

\begin{tabular}{|c|c|c|c|}
\hline & $\begin{array}{l}\text { Significant } \\
\text { correlation }\end{array}$ & $\begin{array}{l}\text { Sign. positive } \\
\text { correlation }\end{array}$ & $\begin{array}{l}\text { Sign. negative } \\
\text { correlation }\end{array}$ \\
\hline $\begin{array}{l}\text { Consumption-to-availability } \\
\text { Ratio (CTA ratio) }\end{array}$ & $28.1 \%$ & $16.8 \%$ & $11.3 \%$ \\
\hline $\begin{array}{l}\text { Water crowding } \\
\text { Index (WCI) }\end{array}$ & $37.9 \%$ & $23.9 \%$ & $14.0 \%$ \\
\hline
\end{tabular}

water availability and consumptive water use, while they lack significant correlations when considering water stress conditions, and vice versa. In Southeast Asia, for example, we observed significant correlations between ENSO and water availability and consumptive water use (Fig. 1), but no significant correlations between ENSO and water stress (Fig. 2).
One explanation for this observation could be that if both water availability and consumptive water use increase or decrease with more or less the same strength under changing JMA SST values, the net effect on the CTA ratio could be insignificant since the ratio between both variables remains equal. All FPUs that show a significant correlation between water resources availability and ENSO-driven climate variability show as well a significant correlation with ENSOdriven variability when looking at the water shortage conditions (Fig. S2). This can be explained by the fact that the WCI is only driven by changes in water availability and population growth, of which the latter factor was fixed in this analysis.

Subsequently, we assessed the percentage anomalies in the median values of water scarcity conditions between El Niño and La Niña years, compared to the median values under all years. Significant anomalies ( $p \leq 0.05$, tested by regular bootstrapping $n=1000$ ) in water scarcity conditions under El Niño and La Niña years, compared to all years, were found for 12.8 and $14.8 \%$ of the global land area using the CTA ratio and the WCI, respectively (Table 4). The strongest anomaly signals were found during the La Niña phase for both water stress and shortage conditions.

Not all regions with a significant anomaly under El Niño years show (significant) anomalies in the opposite direction during La Niña years. For example, Fig. 3 visualizes the asymmetry in the anomalies found during the El Niño and La Niña phase for Latin America. Moreover, areas with significant correlations with the JMA SST index do not always 


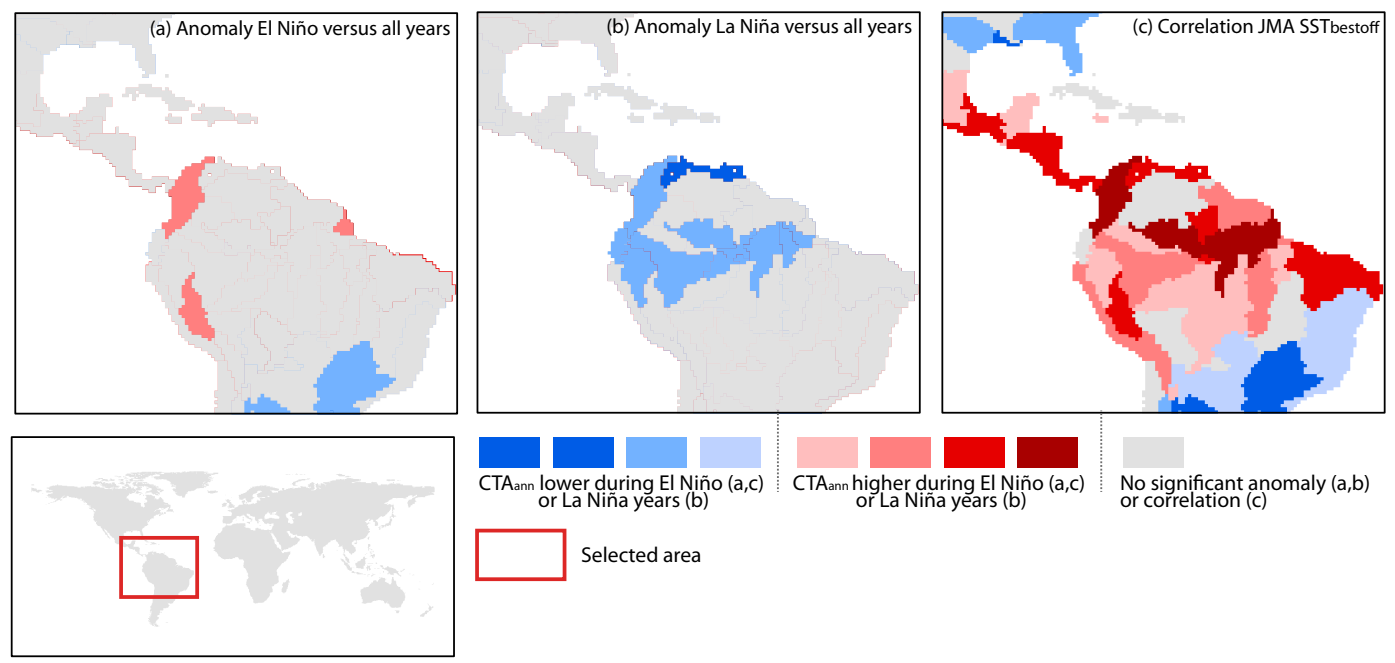

Figure 3. Comparison of results found when studying the (a) anomaly in water scarcity conditions (CTA ratio) between El Niño and all years, (b) anomaly in water scarcity conditions (CTA ratio) between La Niña and all years, and (c) the sensitivity of water scarcity conditions (CTA ratio) to ENSO-driven climate variability measured by means of the JMA SST bestoff. Red colours indicate more severe scarcity conditions under El Niño phases (a, c) or La Niña phases (b). Blue colours indicate less severe scarcity conditions under El Niño phases (a, c) or La Niña phases (b).

(a) Population exposed

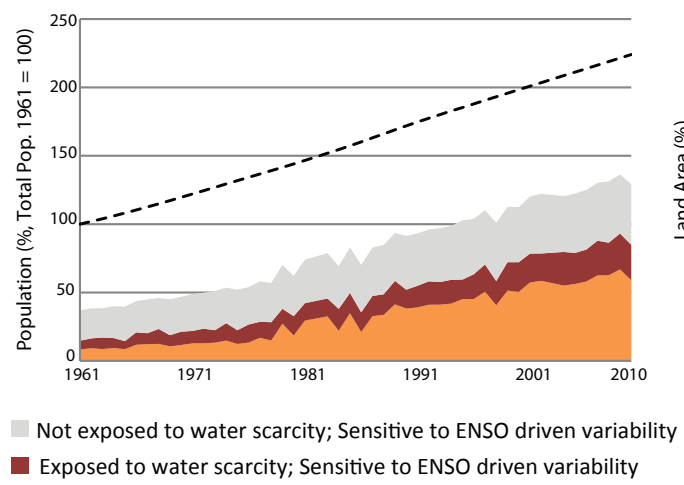

(b) Land area exposed

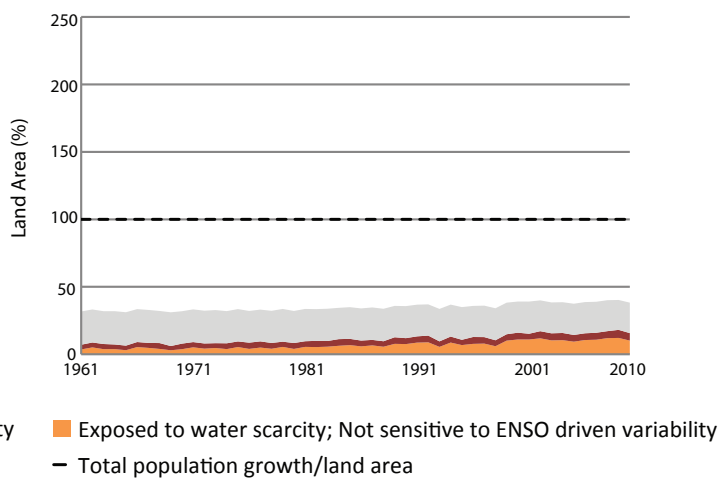

Figure 4. Development of population and land area exposed to water scarcity events and/or being sensitive to ENSO-driven climate variability over the period 1961-2010, as estimated with the CTA ratio. (a) shows the growth in population living under water scarce conditions and/or living in areas sensitive to ENSO-driven climate variability relative to the total growth in global population (set at 100 in 1961). (b) shows the increase in land area exposed to either water scarcity events and/or ENSO-driven climate variability relative to the total global land area (100).

show significant anomalies when looking at the different ENSO phases. This can be explained by the fact that only those years for which the 5-month moving average JMA SST index values are $( \pm) 0.5^{\circ} \mathrm{C}$ or greater (El Niño)/smaller (La Niña) for at least 6 consecutive months (including OctoberDecember) are assigned as El Niño or La Niña years (see Sect. 2.5). Using this ENSO year definition thus disguises all variability in JMA SST values that falls just below the threshold set; i.e. variation that can have, however, a significant effect on water scarcity conditions.

\subsection{Sensitivity of water scarcity events to ENSO under changing socioeconomic conditions}

Due to the socioeconomic developments over the period 1961-2010 water scarcity conditions and their associated impacts intensified, both in the absolute and relative sense (Fig. 4 and Table 5). From 1961 to 2010, using 5-year averaged values, the total global population increased from 2.97 to 6.25 billion. At the same time, we found that the global population exposed to water scarcity events increased from 0.45 billion to 2.47 billion. The global population sensitive to ENSO-driven climate variability increased with a factor 


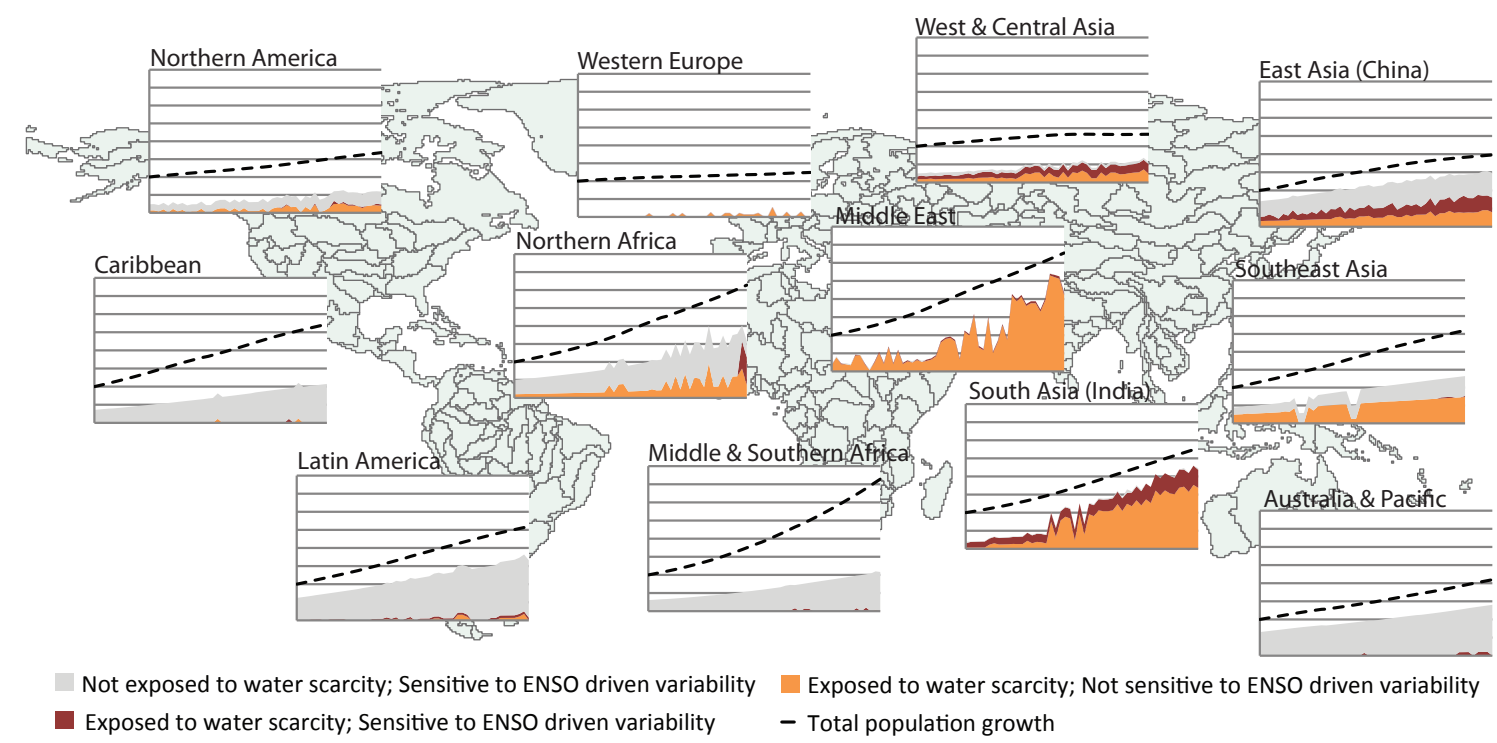

Figure 5. Regional variation in developments of population (\%) exposed to water scarcity events and/or being sensitive to ENSO-driven climate variability over the period 1961-2010, as estimated with the CTA ratio. The figure shows per world region the growth in population living under water scarcity conditions and/or living in areas sensitive to ENSO-driven climate variability, relative to the total growth in global population (set at 100 in 1961). $Y$ axis (\% population) ranges from 0 up to 400.

Table 4. Percentage of the global land area for which FPUs show significant anomalies in the median values of water scarcity conditions between the El Niño (EN) and La Niña (LN) phase, compared to the median values under all years. Water scarcity conditions were assessed by means of the CTA ratio for water stress and WCI ratio for water shortage.

\begin{tabular}{llll}
\hline & $\begin{array}{l}\text { Significant } \\
\text { anomaly }\end{array}$ & $\begin{array}{l}\text { Sign. anomaly } \\
- \text { El Niño phase }\end{array}$ & $\begin{array}{l}\text { Sign. anomaly } \\
- \text { La Niña phase }\end{array}$ \\
\hline $\begin{array}{l}\text { Consumption to } \\
\text { availability }\end{array}$ & $12.8 \%$ & $3.4 \%$ & $12.8 \%$ \\
$\begin{array}{l}\text { Ratio (CTA ratio) } \\
\begin{array}{l}\text { Water crowding } \\
\text { Index (WCI) }\end{array}\end{array}$ & $14.8 \%$ & $6.9 \%$ & $9.5 \%$ \\
\hline
\end{tabular}

of 2.4 over the same time period whilst its proportion to the global total population remained relatively unchanged (Table 5). The population sensitive to ENSO variability and living in areas exposed to water scarcity events currently represent only a minority of the global population $(11.4 \%)$. These results are, however, contrasted with relative high growth factors (Table 5). The impact the spatial clustering of population and consumptive water use, and their unequal growth rates, on water scarcity events is shown by the fact that the share of land area exposed to water scarcity events only doubled over this same period for the CTA ratio (Fig. 4), from 7.4 up to $16.5 \%$ of the global land surface. The results found for water shortage $(\mathrm{WCI} \leq 1700)$ are roughly similar at the global scale (Supplement Fig. S3, Table S1) and therefore not discussed individually in this section.
Regional variations in the population exposed to water stress and/or being sensitive to ENSO-driven climate variability under changing socioeconomic conditions, are visualized in Fig. 5. Although these regional figures do not lend themselves to a similar growth factor analysis, such as executed on the global numbers in Fig. 4, we can distinguish by means of visual inspection different characteristic region types. The first group of regions (Latin America Australia and the Pacific, the Caribbean, and Middle and Southern Africa) experiences significant correlations with ENSO variability for a relative large share of its land area and population ( $\geq 25 \%$ of the total population in 2010) whilst exposure to water scarcity events is low $(<25 \%$ of the total population in 2010). The second group of regions shows both a relatively low sensitivity to ENSO-driven climate variability $(<25 \%$ of the total population in 2010) and low exposure to water scarcity events $(<25 \%$ of the total population in 2010$)$, e.g. northern America and western Europe. For the third group of regions (the Middle East, India, Southeast Asia, and western and central Asia) we find significant water scarcity exposure ( $\geq 25 \%$ of the total population in 2010) but no or relative low sensitivity to ENSO variability $(<25 \%$ of the total population in 2010). Finally, the fourth group of regions shows relatively high exposure to water scarcity events $(\geq 25 \%$ of the total population in 2010) and abundant sensitivity to ENSOdriven climate variability ( $\geq 25 \%$ of the total population in 2010), e.g. China and northern Africa. Comparing these observations with the regional figures found for water shortage events (Supplement Fig. S4), assessed by means of the WCI, we found different results for the regions western and central 
Table 5. Development of (a) the global total population, (b) the global population exposed to water scarcity events (CTA ratio), (c) the global population living in areas sensitive to ENSO-driven climate variability, and (d) the global population being exposed to water scarcity events (CTA ratio) and living in areas sensitive to ENSO-driven climate variability, between 1961 and 2010 using 5-year averaged values. Numbers between brackets show the values expressed in percentage of the total population. Growth factors represent both the absolute increases as well as the relative increases over time.

\begin{tabular}{lllll}
\hline & Total population & $\begin{array}{l}\text { Population exposed } \\
\text { to water scarcity events } \\
(\mathrm{CTA} \geq 0.2)\end{array}$ & $\begin{array}{l}\text { Population sensitive } \\
\text { to ENSO-driven climate variability }\end{array}$ & $\begin{array}{l}\text { Population sensitive } \\
\text { to ENSO-driven climate variability } \\
\text { and exposed to water scarcity events }(\mathrm{CTA} \geq 0.2)\end{array}$ \\
\hline $1961-1965$ & 2.97 billion & 0.45 billion $(15.3 \%)$ & 0.85 billion $(28.7 \%)$ & 0.2 billion $(6.8 \%)$ \\
$2006-2010$ & 6.25 billion & 2.48 billion $(39.6 \%)$ & 1.96 billion $(31.3 \%)$ & 0.71 billion $(11.4 \%)$ \\
Growth factor & 2.1 & $5.5(2.6)$ & $2.3(0.4)$ & $3.5(1.5)$ \\
\hline
\end{tabular}

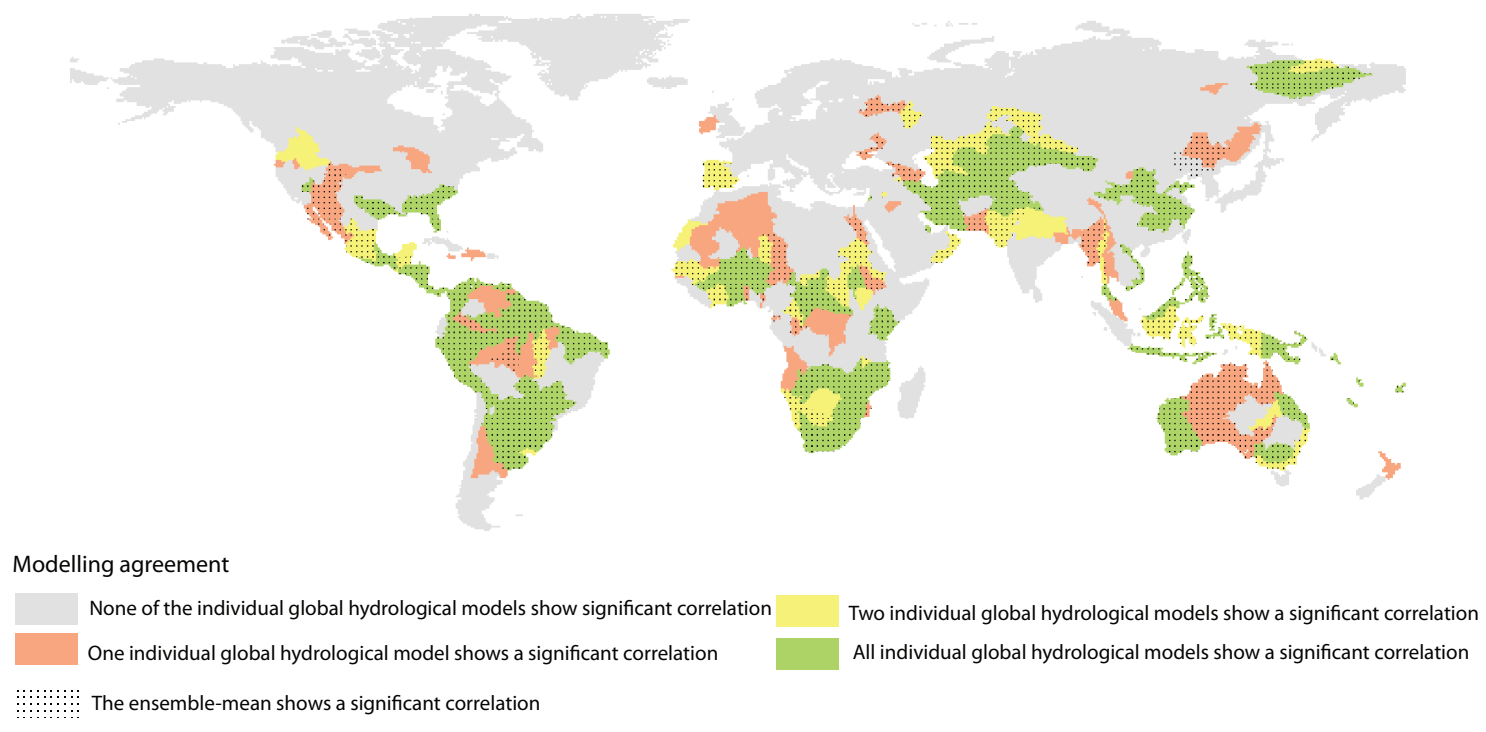

Figure 6. Modelling agreement in observed significant sensitivity of water availability to variation in JMA SST.

Asia (relative high sensitivity to ENSO variability and relative low water scarcity exposure), and middle and southern Africa, the Middle East and Southeast Asia (both experiencing relative high sensitivity to ENSO variability and high exposure to water scarcity events). Using both water scarcity metrics (i.e. CTA ratio and WCI) in combination with the observed growth rates in population and population exposed to water scarcity events enables us to identify those regions where adaptation measures, such as ENSO-based forecasting, have the largest (future) potential in coping with and possibly reducing the adverse impacts of water scarcity events: the Caribbean, Latin America, western and central Asia, middle and southern Africa, northern Africa, the Middle East, China, Southeast Asia and Australia, and the Pacific.

\subsection{Cross-model validation}

The cross-model validation exercise, in which we compared the outcomes of the individual global hydrological models with their ensemble-mean results, reveals that our findings considering the sensitivity of water availability, consumptive water use, and water scarcity conditions to ENSO-driven climate variability are robust in comparison to the use of different hydrological models. We found that for $22.8 \%$ of the global land area $(61.4 \%$ of the total land area with a significant correlation under the ensemble mean) all individual GHMs show a significant correlation to variations in JMA SST in the same direction as the correlation results found under the ensemble means. Correlations found under the ensemble mean are supported by at least one of the global hydrological models for one-third (36.8\%) of the global land surface (Fig. 6), equal to $99.2 \%$ of the land area that shows a significant correlation to the ensemble mean.

A comparison of the individual modelling results with the ensemble mean in terms of the estimated population exposed to water scarcity events and/or living in areas sensitivity to ENSO-driven climate variability shows the modelling spread at the global scale with respect to estimated impacts and their developments over time (Fig. 7). Looking at the 2010 values, we find the smallest percentage difference between models in the estimates of the population exposed to water scarcity events $(+17.2 \%$ CTA ratio, $+21.8 \% \mathrm{WCI})$, and the 
(a) Consumption To Availability Ratio
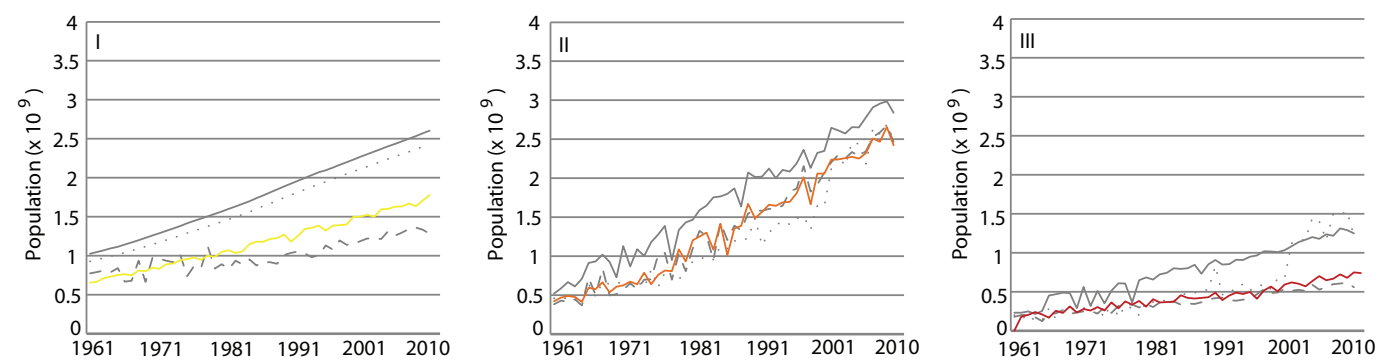

(b) Water Crowding Index
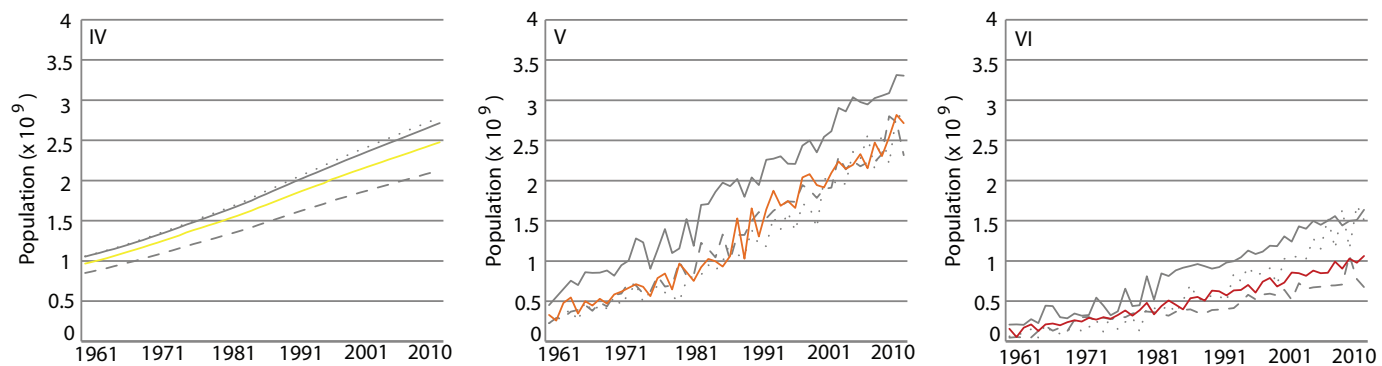

Ensemble-mean: Sensitive to ENSO driven variability

_ Ensemble-mean: Exposed to water scarcity

.... STREAM results

- - PCR-GLOBWB results

_ Ensemble-mean: Exposed to water scarcity \& Sensitive to ENSO driven variability

WaterGAP results

Figure 7. Development of the population exposed to water scarcity events (CTA ratio) and/or being sensitive to ENSO-driven climate variability over the period 1961-2010, as assessed by the individual global hydrological models (STREAM, PCR-GLOBWB, and WaterGAP) and the ensemble mean. (I) and (IV) show the development in population sensitive to ENSO-driven climate variability as estimated under the ensemble-mean (yellow) and individual GHMs (grey). (II) and (V) present the increase in population exposed to water scarcity events for the ensemble-mean (orange) and individuals GHMs (grey). (III) and (VI) visualize the amount of people being exposed to water scarcity events, while at the same time living in areas with a significant correlation to ENSO-driven climate variability for the ensemble-mean (red) and individual GHMs (grey).

largest variations when looking at the population both being exposed to water scarcity events and living in areas sensitive to ENSO-driven climate variability $(+68.9 \%$ CTA ratio, $+54.2 \% \mathrm{WCI})$. Percentage deviations were found to be smaller when looking at the land area exposed (Supplement Fig. S5). As shown in Fig. 7 and Fig. S5, the inter-model comparison reveals that the impact estimates of the ensemble mean are conservative when comparing them with the individual modelling results, especially when looking at the population or land area sensitive to ENSO variability and/or being exposed to water scarcity events.

\section{Discussion}

Within this study we found that both water resources availability and water scarcity conditions can be significantly correlated with ENSO-driven climate variability as measured with the JMA SST index for a relatively large share of the global land area. Due to clustering effects we found even larger proportions when looking at the population living in these areas.
Regions well-known for their correlation of precipitation and hydrological extremes with ENSO variability (Dai and Wigley, 2000; Dettinger and Diaz, 2000; Ropelewski and Halpert., 1987; Vicente-Serrano et al., 2011; Ward et al., 2010, 2014a) also showed a statistically significant correlation between ENSO and annual total water resources availability or water scarcity conditions. This makes sense as precipitation deficits feed droughts, which possibly results in water scarcity events if consumptive demands outweigh the available water resources. On the other hand, precipitation surpluses might result in increased water levels, floods, and increased flood risk but at the same time decreased water scarcity conditions. When comparing our results on water resources availability to these previous studies, we find corresponding significant correlations in the regions of midwest North America, the Caribbean, Latin America, southern Africa, Southeast and central Asia, and the Pacific. Moreover, the sign of the correlations found within four large river basins in Latin America and Africa, (Amazon Congo, Paraná, and Nile) is supported by earlier estimates of Amarasekera et al. (1997) who assessed the correlation between 
ENSO and the natural variability in the flow of tropical rivers. Significant correlations as shown for other regions were also found in case studies focusing on northern America (e.g. Clark II et al., 2014; Schmidt et al., 2001), Southeast Asia (e.g. Lü et al., 2011; Räsänen and Kummu, 2013), southern Africa (e.g. Meque and Abiodun, 2014; Richard et al., 2001), and Australia (e.g. Chiew et al., 2011; Dutta et al., 2006). The spatial variation in the sign of the found correlation is in line with the results of Ward et al. (2014a), who found that annual flood and mean discharge values intensify under La Niña and decline when moving towards El Niño phases globally in more areas than the other way around.

In line with earlier research (e.g. Meza et al., 2005; Islam and Gan, 2015) we would have expected to find more areas with a significant correlation between consumptive water use and ENSO-driven climate variability. A number of explanations could be given for the absence of significant correlations patterns in this study: (1) the consumptive water use estimates used in this study are calculated by means of multiple socioeconomic and hydro-climatic proxies and variables, such as extent of irrigated areas, number of livestock, GDP, (long-term mean) monthly temperatures, and precipitation estimates, and should be interpreted as potential consumptive water use; (2) of these variables only irrigation water use could be linked directly to ENSO-driven climate variability by means of its temperature and precipitation input variables. Fixed consumption numbers in other sectors might attenuate therefore the variability found within the irrigation sector; (3) yearly totals of consumptive water use were applied in this study to assess its sensitivity to ENSO-driven climate variability whereas it might be more appropriate for consumptive water use to assess its correlation either using monthly timescales or yearly maxima; and (4) climate-driven variations in irrigation water demands are the result of changes in crop evapotranspiration and changes in green water availability, which do not have a unequivocal relation with ENSO-driven climate variability at all times, but are partly determined by the month-specific cropping calendar and antecedent conditions, such as the memory of the soil. Soil memory is often referred to as the persistence of the soil to anomalous wet or dry conditions long after these conditions occurred in the atmosphere or any other stage of the hydrological cycle which could lead to time lags and attenuation of the meteorological signal (Seneviratne et al., 2006; Liu and Avissar, 1999). The found variability in the irrigation water demand estimates might, therefore, be out of phase with the variability found in the atmospheric conditions (ENSO-driven climate variability as assessed by the JMA SST anomaly index) which, in turn, explains the relative low significant correlation. Including, per region or soil characteristic area, the size of the soil memory as a time lag could potentially improve the correlation of consumptive (irrigation) water demand with ENSO-driven climate variability. More research is, however, needed in order to be able to express this relation between the size of the soil memory and the time lag used within the ENSO correlation analysis.

The analysis presented in this study revealed that interannual variability itself, such as the ENSO-driven climate variability, is often not enough to cause water scarcity events to actually occur. We found that it is a combination of multiple hydro-climatic factors, such as the mean water resources availability and its inter-annual variability around the mean, together with the prevalent socioeconomic conditions, that determines the susceptibility of a region to water scarcity events, a finding earlier suggested by Veldkamp et al. (2015) and Wada et al. (2011a), and its implications being discussed in Hall and Borgomeo (2013). The actual impact of water scarcity events depends, moreover, not only on the number of people exposed or the severity of a water scarcity event itself, but on how sensitive this population is to water scarcity conditions, whether and how efficiently governments can deal with water scarcity problems, and how many (financial and infrastructural) resources are available to cope with these water scarce conditions (Grey and Sadoff, 2007; Hall and Borgomeo, 2013).

Given the substantial share of land area, and the even higher rates of population, for which water resources availability and water scarcity conditions show significant correlations with ENSO-driven climate variability there is a large potential for ENSO-based adaptation and risk reduction to cope with water scarcity events and their associated impacts. The relative importance of ENSO-driven climate variability in the year-to-year-variability as found in this study could assist water managers and decisions makers in the design of adaptation strategies, such as in optimizing the use of existing reservoir facilities in Australia (Sharma, 2000). Moreover, the potential predictability of ENSO, with lead times up to several months, may help in the prioritization of (ex ante) efforts in disaster risk reduction, such as pre-stocking foods and disaster relief goods or crop insurance systems based on ENSO indices (Coughlan de Perez et al., 2014, 2015; Dilley, 2000; Suarez et al., 2008). The potential added value of adaptation measures targeted towards mitigating the impacts of inter-annual variability is high, as it is especially this variability that people find difficult to cope with (Smit and Pilifosova, 2003). In this paper we looked, however, at naturalized flows, so reservoirs or inter-basin transfers have not yet been taken into account. Future research should therefore, first evaluate whether (virtual) water trading and water storage mechanisms are effective in reducing water scarcity conditions and whether management could be optimized using ENSO-forecasting parameters and at what costs.

To get more insight in the expected correlation between ENSO, and water resources and scarcity conditions under longer term climate change and socioeconomic developments, future research could use extreme JMA SST values as a test case in combination with the correlation values found to amplify the water resources and scarcity conditions under extreme events. Recent research showed that these ex- 
treme ENSO events may become more frequent in the future (Cai et al., 2014; IPCC, 2013; Power et al., 2013). The uncertainty among the different climate models is, however, large and at the same time there is no agreement yet on the attribution of long-term climate change to increases in the sensitivity and frequency of ENSO events (van Oldenborgh et al., 2005; Paeth et al., 2008; Guilyardi et al. 2009). Considering a continuous increase in population growth and water scarcity impacts in the future, hotspots could be identified that have to deal with water scarcity events and are sensitive to ENSO-driven variability at the same time. One should take into account, however, that we assumed in this study that the correlations found between water availability, consumptive water use, and water scarcity conditions, and the JMA SST index value remain stationary over time. In reality, the strength of correlations between hydrological parameters and ENSO can change over time (Ward et al., 2014a). Further research is therefore needed to assess whether, how much, and in which direction these observed correlation values change under the combination of changing climatic conditions and historic and future socioeconomic developments. Moreover, ENSO is part of an ocean-atmospheric climate variability system that constitutes many more subregional systems and local circulation patterns (e.g. Indian monsoon, Pacific/North America pattern, North Atlantic Oscillation, East Atlantic/West Russia pattern, Scandinavia pattern) which modulate the ENSO signal (Hannaford et al., 2011). Future research should look into the sensitivity of water resources availability and scarcity conditions to combinations of these systems.

Global assessment studies, such as the one presented here, are well able to identify the impact of ENSO on global-scale patterns of water scarcity. These types of studies are therefore well-suited for a first-order problem definition or for the large-scale prioritization of adaptation efforts. When interpreting these assessments one should keep in mind, however, that these studies should always be complemented with local or regional-scale analyses to assess the actual level of water scarcity on the ground, their (economic) consequences, and regional or local-scale potential for ENSO forecasting as adaptation strategy to cope with water scarcity events.

\section{Conclusions}

Within this contribution, we executed the first global-scale sensitivity assessment of blue water availability, consumptive water use, and water scarcity to ENSO-driven climate variability. Throughout this paper we have shown that regional water scarcity conditions become more extreme under El Niño and La Niña phases covering a relative large proportion $(>28.1 \%)$ of the global land area. Due to the spatial clustering of population and consumptive water use we found even larger shares $(>31.4 \%$ of the total population in 2010) when looking at the population living in these ar- eas being sensitive to ENSO-driven climate variability. The exposure of a region to water scarcity events is determined by both hydro-climatic and socioeconomic conditions. Results on exposure to water scarcity events, found in this study, provide mixed signals. We found that the population that is currently exposed to water scarcity events consists of less than half of the global population (CTA ratio: $39.6 \%$; WCI: $41.1 \%$ ), whilst the population sensitive to ENSO variability and living in areas exposed to water scarcity events represent only a minority of the global population (CTA ratio: $11.4 \%$; WCI: $15.9 \%$ ). These results are, however, contrasted by relative differences in growth rates under changing socioeconomic conditions, which are higher in regions exposed to water scarcity events than in regions that do not experience any water scarcity.

Given the correlations found in this study for water availability and water scarcity conditions with ENSO-driven climate variability, and having seen the developments in the population and land area exposed to water scarcity events and/or being sensitive to ENSO-driven variability under changing socioeconomic conditions, we found that there is large potential for ENSO-based adaptation and risk reduction. The observed regional variations could thereby accommodate in a first-cut prioritization for such adaptation strategies. Moreover, the results presented in this study show that there is both potential and need for more research on the issue of ENSO and water scarcity with emerging topics related to the economic impacts of water scarcity, the assessment of consumptive water use and its temporal variability, the combined impact of large-scale oscillation systems on water resources and water scarcity conditions, and the transferability of global-scale insights to local-scale implications and decisions.

\section{The Supplement related to this article is available online at doi:10.5194/hess-19-4081-2015-supplement.}

Author contributions. T. I. E. Veldkamp, J. C. J. H. Aerts, and P. J. Ward designed research; T. I. E. Veldkamp, S. Eisner and Y. Wada prepared data sets; T. I. E. Veldkamp analyzed data; and T. I. E. Veldkamp, S. Eisner, Y. Wada, J. C. J. H. Aerts, and P. J. Ward wrote the paper.

Acknowledgements. We thank the editor and two anonymous reviewers for their valuable comments. The research leading to this article is partly funded by the EU 7th Framework Programme through the projects ENHANCE (grant agreement no. 308438) and Earth2Observe (grant agreement no. 603608). J. Aerts received funding from the Netherlands Organisation for Scientific Research (NWO) VICI (grant no. 453-14-006). Y. Wada is supported by Japan Society for the Promotion of Science (JSPS) Oversea 
Research Fellowship (grant no. JSPS-2014-878). P. Ward received funding from the Netherlands Organisation for Scientific Research (NWO) in the form of a VENI grant (grant no. 863-11-011).

Edited by: J. Hannaford

\section{References}

Aerts, J. C. J. H., Kriek, M., and Schepel, M.: STREAM (Spatial Tools for River Basins and Environment and Analysis of Management Options): "Set Up and Requirements.", Phys. Chem. Earth Pt. B, 24, 591-595, 1999.

Alcamo, J., Döll, P., Kaspar, F., and Siebert, S.: Global change and global scenarios of water use and availability: An Application of WaterGAP1.0, University of Kassel, Germany, p. 47, 1997.

Alcamo, J., Döll, P., Henrichs, T., Kaspar, F., Lehner, B., Rösch, T., and Siebert, S.: Global estimates of water withdrawals and availability under current and future "business-as-usual" conditions, Hydrolog. Sci. J., 48, 339348, doi:10.1623/hysj.48.3.339.45278, 2003.

Alcamo, J., Flörke, M., and Märker, M.: Future long-term changes in global water resources driven by socioeconomic and climatic changes, Hydrolog. Sci. J., 52, 247-275, doi:10.1623/hysj.52.2.247, 2007.

Amarasekera, K. N., Lee, R. F., Williams, E. R., and Eltahir, E. A. B.: ENSO and the natural variability in the flow of tropical rivers, J. Hydrol., 200, 24-39, doi:10.1016/S0022-1694(96)03340-9, 1997.

Arnell, N. W.: Climate change and global water resources, Environmental Change, 9, S31-S49, 1999.

Arnell, N. W.: Effects of IPCC SRES* emissions scenarios on river runoff: a global perspective, Hydrol. Earth Syst. Sci., 7, 619-641, doi:10.5194/hess-7-619-2003, 2003.

Bouma, M. J., Kovats, R. S., Goubet, S. A., Cox, J. S. H., and Haines, A. T.: Global assessment of El Niño' s disaster burden, The Lancet, 350, 1435-1438, 1997.

Brown, A. and Matlock, M. D.: A Review of Water Scarcity Indices and Methodologies, The Sustainability Consortium White paper (No. 106), University of Arkansas, http://www.sustainabilityconsortium.org/wpcontent/themes/sustainability/assets/pdf/whitepapers (last access: 7 October 2015), 21 pp., 2011.

Cai, W., Borlace, S., Lengaigne, M., van Rensch, P., Collins, M., Vecchi, G., Timmermann, A., Santoso, A., McPhaden, M.J., Wu, L., England, M. H., Wang, G., Guilyardi, E., and Jin, F.-F.: Increasing frequency of extreme El Niño events due to greenhouse warming, Nature Climate Change, 4, 111-116, doi:10.1038/nclimate2100, 2014.

Cai, X. M. and Rosegrant, M. W.: Global Water Demand and Supply Projections, Water Int., 27, 159-169. doi:10.1080/02508060208686989, 2002.

Cheng, Y., Tang, Y., and Chen, D.: Relationship between predictability and forecast skill of ENSO on various time scales, J. Geophys. Res., 116, C12006, doi:10.1029/2011JC007249, 2011.

Chiew, F. H. S. and McMahon, T. A.: Global ENSOstreamflow teleconnection, streamflow forecasting and interannual variability, Hydrolog. Sci. J., 47, 505-522, doi:10.1080/02626660209492950, 2002.
Chiew, F. H. S., Piechota, T. C., Dracup, J. A., and McMahon, T. A.: El Nino Southern Oscillation and Australian rainfall, streamflow and drought: Links and potential for forecasting, J. Hydrol., 204, 138-149, doi:10.1016/S0022-1694(97)00121-2, 1998.

Chiew, F. H. S., Young, W. J., Cai, W., and Teng, J.: Current drought and future hydroclimate projections in southeast Australia and implications for water resources management, Stoch. Env. Res. Risk A., 25, 601-612, doi:10.1007/s00477-010-0424-x, 2011.

Clark II, C., Nnaji, G. A., and Huang, W.: Effects of f El-Niño and a La-Niña Sea Surface Temperature Anomalies on Annual Precipitations and Streamflow Discharges in Southeastern United States, J. Coastal Res., 68, 113-120, doi:10.2112/SI68-015.1, 2014.

Cosgrove, W. and Rijsberman, F.: World water vision: Making water everybody's business, Earthscan, London, 2000.

Coughlan de Perez, E., Monasso, F., van Aalst, M., and Suarez, P.: Science to prevent disasters, Nat. Geosci., 7, 78-79, doi:10.1038/ngeo2081, 2014.

Coughlan de Perez, E., van den Hurk, B., van Aalst, M. K., Jongman, B., Klose, T., and Suarez, P.: Forecast-based financing: an approach for catalyzing humanitarian action based on extreme weather and climate forecasts, Nat. Hazards Earth Syst. Sci., 15, 895-904, doi:10.5194/nhess-15-895-2015, 2015.

Dai, A. and Wigley, T. M. L.: Global patterns of ENSOinduced precipitation, Geophys. Res. Lett., 27, 1283-1986, doi:10.1029/1999GL011140, 2000.

De Fraiture, C.: Integrated water and food analysis at the global and basin level. An application of WATERSIM, Water Resour. Manag., 21, 185-198, doi:10.1007/s11269-006-9048-9, 2007.

Dettinger, M. D. and Diaz, H. F.: Global Characteristics of Stream Flow Seasonality and Variability, J. Hydrometeorol., 1, 289-310, 2000.

Dettinger, M. D., Cayan, D. R., Mccabe, G. J., and Marengo, J. A.: Multiscale streamflow variability associated with El Niño/Southern Oscillation, in: El Nino and the Southern Oscillation - Multiscale Variability and Global and Regional Impacts, Cambridge University Press, Cambridge, 113-146, 2000.

Dilley, M.: Reducing vulnerability to climate variability in Southern Africa: The growing role of climate information, Climatic Change, 45, 63-73, 2000.

Dilley, M. and Heyman, B. N.: ENSO and Disaster: Droughts, Floods and El Nino/Southern Oscillation warm Events, Disasters, 19, 181-193, 1995.

Döll, P. and Lehner, B.: Validation of a new global 30-min drainage direction map, J. Hydrol., 258, 214-231, doi:10.1016/S00221694(01)00565-0, 2002.

Dutta, S. C., Ritchie, J. W., Freebairn, D. M., and Abawi, G. Y.: Rainfall and streamflow response to El Niño Southern Oscillation: a case study in a semiarid catchment, Australia, Hydrolog. Sci. J., 51, 1006-1020, doi:10.1623/hysj.51.6.1006, 2006.

Falkenmark, M.: Growing water scarcity in agriculture?: future challenge to global water security, Philos. T. R. Soc. A, 371, 20120410, doi:10.1098/rsta.2012.0410, 2013.

Falkenmark, M., Jundqvist, L., and Widstrand, C.: Macro-scale water scarcity requires micro-scale approaches: aspects of vulnerability in semi-arid development, Nat. Resour. Forum, 13, 258267, doi:10.1111/j.1477-8947.1989.tb00348.x, 1989.

Falkenmark, M., Berntell, A., Jagerskog, A., Lundqvist, J., Matz, M., and Tropp, H.: On the Verge of a New Water Scarcity: A 
Call for Good Governance and Human Ingenuity, Stockholm International Water Institute (SIWI), Stockholm, 2007.

Gerten, D., Heinke, J., Hoff, H., Biemans, H., Fader, M., and Waha, K.: Global Water Availability and Requirements for Future Food Production, J. Hydrometeorol., 12, 885-899, doi:10.1175/2011JHM1328.1, 2011.

Guilyardi, E., Wittenberg, A., Fedorov, A., Collins, M., Wang, C., Capotondi, A., van Oldenborgh, G. J., and Stockdale, T.: Understanding El Niño in ocean-atmosphere general circulation models, Progress and challenges, B. Am. Meteorol. Soc., 90, 325340, doi:10.1175/2008BAMS2387.1, 2009.

Grey, D. and Sadoff, C. W.: Sink or Swim? Water security for growth and development, Water Policy, 9, 545, doi:10.2166/wp.2007.021, 2007.

Gudmundsson, L., Wagener, T., Tallaksen, L. M., and Engeland, K.: Evaluation of nine large-scale hydrological models with respect to the seasonal runoff climatology in Europe, Water Resour. Res., 48, W11504, doi:10.1029/2011WR010911, 2012.

Haddeland, I., Heinke, J., Voß, F., Eisner, S., Chen, C., Hagemann, S., and Ludwig, F.: Effects of climate model radiation, humidity and wind estimates on hydrological simulations, Hydrol. Earth Syst. Sci., 16, 305-318, doi:10.5194/hess-16-305-2012, 2012.

Haddeland, I., Heinke, J., Biemans, H., Eisner, S., Flörke, M., Hanasaki, N., Konzmann, M., Ludwig, F., Masaki, Y., Schewe, J., Stacke, T., Tessler, Z.D., Wada, Y., and Wisser, D.: Global water resources affected by human interventions and climate change, P. Natl. Acad. Sci. USA, 111, 3251-3256, doi:10.1073/pnas.1222475110, 2014.

Hall, J. and Borgomeo, E.: Risk-based principles for defining and managing water security Risk-based principles for defining and managing water security, Philos. T. R. Soc. A, 371, 20120407, doi:10.1098/rsta.2012.0407, 2013.

Hanasaki, N., Fujimori, S., Yamamoto, T., Yoshikawa, S., Masaki, Y., Hijioka, Y., Kainuma, M., Kanamori, Y., Masui, T., Takahashi, K., and Kanae, S.: A global water scarcity assessment under Shared Socio-economic Pathways - Part 2: Water availability and scarcity, Hydrol. Earth Syst. Sci., 17, 2393-2413, doi:10.5194/hess-17-2393-2013, 2013.

Hanemann, W. M.: The economic conception of water, in: Water Crisis: myth or reality?, Taylor \& Francis/Balkema, Leiden, the Netherlands, 61-90, 2006.

Hannaford, J., Lloyd-Hughes, B., Keef, C., Parry, S., and Prudhomme, C.: Examining the large-scale spatial cohoerence of European drought using regional indicators of precipitation and streamflow deficit, Hydrol. Process., 24, 1146-1162, doi:10.1002/hyp.7725, 2011.

Hannah, D. M., Demuth, S., van Lanen, H. A. J., Looser, U., Prudhomme, C., Rees, G., Stahl, K., and Tallaksen, L. M.: Large-scale river flow archives: importance, current status and future needs, Hydrol. Process., 25, 1191-1200, doi:10.1002/hyp.7794, 2011.

Hoekstra, A. Y., Chapagain, A. K., Aldaya, M. M., and Mekonnen, M. M.: Water footprint assessment manual: Setting the global standard, Earthscan, London, UK, 2011.

Hoekstra, A. Y., Mekonnen, M. M., Chapagain, A. K., Mathews, R. E., and Richter, B. D.: Global monthly water scarcity: blue water footprints versus blue water availability, PloS One, 7, e32688, doi:10.1371/journal.pone.0032688, 2012.

Howell, L.: Global Risks 2013, World Economic Forum, Geneva, Switzerland, 2013.
Hulme, M., Barrow, E. M., Arnell, N. W., Harrison, P. A., and Johns, T. C.: Relative impacts of human-induced climate change and natural climate variability, Nature, 397, 688-691, 1999.

IPCC: Summary for Policymakers. Climate Change 2013: The Physical Science Basis, Contribution of Working Group I to the Fifth Assessment Report of the Intergovernmental Panel on Climate Change, Cambridge University Press, Cambridge, UK, 2013.

Islam, Z. and Gan, T. Y.: Future irrigation demand of South Saskatchewan river basin under the combined impacts of climate change and El Nino Southern Oscillation, Water Resour. Manage., 29, 2091-2105, doi:10.1007/s11269-015-0930-1, 2015.

Kiem, A. S. and Franks, S. W.: On the identification of ENSO-induced rainfall and runoff variability: a comparison of methods and indices, Hydrolog. Sci. J., 46, 715-727, doi:10.1080/02626660109492866, 2001.

Kiguchi, M., Shen, Y., Kanae, S., and Oki, T.: Reevaluation of future water stress due to socioeconomic and climate factors under a warming climate, Hydrolog. Sci. J., 601, 14-29, doi:10.1080/02626667.2014.888067, 2015.

Kiladis, G. N. and Diaz, H. F.: Global climatic anomalies associated with extremes in the Southern Oscillation, J. Climate, 2, 10691090, 1989.

Klein Goldewijk, K. and van Drecht, G.: HYDE 3: Current and historical population and land cover, in: Integrated modelling of global environmental change. An overview of IMAGE 2.4, edited by: Bouwman, A. F., Kram, T., and Klein Goldewijk, K., Netherlands Environmental Assessment Agency (MNP), Bilthoven, 2006.

Kovats, R. S., Bouma, M. J., Hajat, S., Worrall, E., and Haines, A.: El Niño and health, The Lancet, 362, 1481-1489, doi:10.1016/S0140-6736(03)14695-8, 2003.

Kummu, M., Ward, P. J., de Moel, H., and Varis, O.: Is physical water scarcity a new phenomenon? Global assessment of water shortage over the last two millennia, Environ. Res. Lett., 5, 034006, doi:10.1088/1748-9326/5/3/034006, 2010.

Kummu, M., Gerten, D., Heinke, J., Konzmann, M., and Varis, O.: Climate-driven interannual variability of water scarcity in food production potential: a global analysis, Hydrol. Earth Syst. Sci., 18, 447-461, doi:10.5194/hess-18-447-2014, 2014.

Kundzewicz, Z. W., Mata, L. J., Arnell, N., Döll, P., Kabat, P., Jiménez, B., Miller, K., Oki, T., Şen, Z., and Shiklomanov, I.: Freshwater resources and their management. Climate Change 2007: Impacts, Adaptation and Vulnerability. Contribution of Working Group II to the Fourth Assessment Report of the Intergovernmental Panel on Climate Change, edited by: Parry, M. L., Canziani, O. F., Palutikof, J. P., van der Linden, P. J., and Hanson, C. E., Cambridge University Press, UK, http://www.ipcc.ch/pdf/ assessment-report/ar4/wg2/ar4-wg2-chapter3.pdf (last access: 8 January 2008), 173-210, 2007.

Labat, D.: Cross wavelet analyses of annual continental freshwater discharge and selected climate indices, J. Hydrol., 385, 269-278, doi:10.1016/j.jhydrol.2010.02.029, 2010.

Lehner, B., Döll, P., Alcamo, J., Henrichs, T., and Kaspar, F.: Estimating the Impact of Global Change on Flood and Drought Risks in Europe: A Continental, Integrated Analysis, Climatic Change, 75, 273-299, doi:10.1007/s10584-006-6338-4, 2006.

Liu, Y. and Avissar, R.: A study of persistence in the landatmosphere system using a general circulation model and 
observations, J. Climate, 12, 2139-2153, doi:10.1175/15200442(1999)012<2139:ASOPIT>2.0.CO;2, 1999.

Livezey, R. E. and Chen, W. Y.: Statistical field significance and its determination by monte carlo techniques, Mon. Weather Rev., 111, 46-59, 1982.

Lü, A., Jia, S., Zhu, W., Yan, H., Duan, S., and Yao, Z.: El NiñoSouthern Oscillation and water resources in the headwaters region of the Yellow River: links and potential for forecasting, Hydrol. Earth Syst. Sci., 15, 1273-1281, doi:10.5194/hess-15-12732011, 2011.

Ludescher, J., Gozolchiani, A., Bogachev, M. I., Bunde, A., Havlin, S., and Schellnhuber, H. J.: Correction for Ludescher et al., Improved El Nino forecasting by cooperativity detection, P. Natl. Acad. Sci. USA, 110, 19172-19173, doi:10.1073/pnas.1317354110, 2013.

Ludescher, J., Gozolchiani, A., Bogachev, M. I., Bunde, A., Havlin, S., and Schellnhuber, H. J.: Very early warning of next El Niño, P. Natl. Acad. Sci. USA, 111, 2064-2066, doi:10.1073/pnas.1323058111, 2014.

Lundqvist, J. and Falkenmark, M.: Adaptation to Rainfall Variability and Unpredictability: New Dimensions of Old Challenges and Opportunities, Int. J. Water Resour. D., 26, 595-612, doi:10.1080/07900627.2010.519488, 2010.

McPhaden, M. J., Zebiak, S. E., and Glantz, M. H.: ENSO as an integrating concept in earth science, Science, 314, 1740-1745, doi:10.1126/science.1132588, 2006.

Meque, A. and Abiodun, B. J.: Simulating the link between ENSO and summer drought in Southern Africa using regional climate models, Clim. Dynam., 44, 1881-1900, doi:10.1007/s00382014-2143-3, 2014.

Meza, F. J.: Variability of reference evapotranspiration and water demands. Association to ENSO in the Maipo river basin, Chile, Global Planet. Change, 47, 212-220, doi:10.1016/j.gloplacha.2004.10.013, 2005.

Mosley, M. P.: Regional differences in the effects of El Niño and La Niña on low flows and floods, Hydrolog. Sci. J., 45, 249-267, doi:10.1080/02626660009492323, 2000.

Moss, M. E., Pearson, C. P., and McKerchar, A. I.: The Southern Oscillation index as a predictor of the probability of low streamflows in New Zealand, Water Resour. Res., 30, 2717-2723, 1994.

Müller Schmied, H., Eisner, S., Franz, D., Wattenbach, M., Portmann, F. T., Flörke, M., and Döll, P.: Sensitivity of simulated global-scale freshwater fluxes and storages to input data, hydrological model structure, human water use and calibration, Hydrol. Earth Syst. Sci., 18, 3511-3538, doi:10.5194/hess-18-35112014, 2014.

Murphy, J., Kattsov, V., Keenlyside, N., Kimoto, M., Meehl, G., Mehta, V., Pohlman, H., Scaife, A., and Smith, D.: Towards Prediction of Decadal Climate Variability and Change, Procedia Environmental Sciences, 1, 287-304, doi:10.1016/j.proenv.2010.09.018, 2010.

Nazemi, A. and Wheater, H. S.: On inclusion of water resource management in Earth system models - Part 1: Problem definition and representation of water demand, Hydrol. Earth Syst. Sci., 19, 33-61, doi:10.5194/hess-19-33-2015, 2015a.

Nazemi, A. and Wheater, H. S.: On inclusion of water resource management in Earth system models - Part 2: Representation of water supply and allocation and opportunities for improved modeling, Hydrol. Earth Syst. Sci., 19, 63-90, doi:10.5194/hess19-63-2015, 2015b.

Oki, T. and Kanae, S.: Global hydrological cycles and world water resources, Science, 313, 1068-1072, doi:10.1126/science.1128845, 2006.

Oki, T., Agata, Y., Kanae, S., Saruhashi, T., Yang, D., and Musiake, K.: Global assessment of current water resources using total runoff integrating pathways, Hydrolog. Sci. J., 46, 983-995, doi:10.1080/02626660109492890, 2001.

Paeth, H., Scholten, A., Friederichs, P., and Hense, A.: Uncertainties in climate change prediction: El Niño Southern Oscillation and monsoons, Global Planet. Change, 60, 265-288, doi:10.1016/j.gloplacha.2007.03.002, 2008.

Parker, D., Folland, C., Scaife, A., Knight, J., Colman, A., Baines, P., and Dong, B.: Decadal to multidecadal variability and the climate change background, J. Geophys. Res.-Atmos., 112, D18115, doi:10.1029/2007JD008411, 2007.

Piechota, T. C. and Dracup, J. A.: Long-range forecasting using ElNino Southern Oscillations indicators, J. Hydrol. Eng., 4, 144$151,1999$.

Power, S., Delage, F., Chung, C., Kociuba, G., and Keay, K.: Robust twenty-first-century projections of El Niño and related precipitation variability, Nature, 502, 541-545, doi:10.1038/nature12580, 2013.

Prudhomme, C., Giuntoli, I., Robinson, E. L., Clark, D. B., Arnell, N. W., Dankers, R., Fekete, B. M., Franssen, W., Gerten, D., Gosling, S. N., Hagemann, S., Hannah, D. M., Kim, H., Masaki, Y., Satoh, Y., Stacke, T., Wada, Y., and Wisser, D.: Hydrological droughts in the 21 st century, hotspots and uncertainties from a global multimodel ensemble experiment, P. Natl. Acad. Sci USA, 111, 3262-3267, doi:10.1073/pnas.1222473110, 2014.

Räsänen, T. A. and Kummu, M.: Spatiotemporal influences of ENSO on precipitation and flood pulse in the Mekong River Basin, J. Hydrol., 476, 154-168, doi:10.1016/j.jhydrol.2012.10.028, 2013.

Raskin, P., Gleick, P., Kirshen, P., Pontius, G., and Strzepek, K.: Water Futures: As-sessment of long-range patterns and problems, Comprehensive assessment of the freshwater resources of the world, Stockholm Environment Institute, Stockholm, Sweden, 1997.

Richard, Y., Fauchereau, N., Poccard, I., Rouault, M., and Trzaska, S.: 20th century droughts in southern africa: spatial and temporal variability, teleconnections with oceanic and atmospheric conditions, Int. J. Climatol., 21, 873-885, doi:10.1002/joc.656, 2001.

Richter, B. D., Davis, M. M., Apse, C., and Konrad, C.: A presumptive standard for environmental flow protection, River Res. Appl., 28, 1312-1321, doi:10.1002/rra.1511, 2011.

Rijsberman, F.: Water scarcity: Fact or fiction?, Agr. Water Manage., 80, 5-22, doi:10.1016/j.agwat.2005.07.001, 2006.

Ropelewski, C. F. and Halpert, M. S.: Global and regional scale precipitation patterns associated with the El Nino/Southern Oscillation, Mon. Weather Rev., 115, 1606-1626, 1987.

Rosegrant, M. W., Cai, X. M., and Cline, S.: World water and food to 2025, Dealing with scarcity, International Food Policy Research Institute, Washington, DC, 2002.

Rosenzweig, C. and Hillel, D.: Climate variability and the global harvest: Impacts of El Nino and other oscillations on agroecosystems, Oxford University Press, New York, p. 280, 2008. 
Savenije, H. H. G.: Water scarcity indicators; the deception of the numbers, Phys. Chem. Earth Pt. B, 25, 199-204, doi:10.1016/S1464-1909(00)00004-6, 2000.

Schewe, J., Heinke, J., Gerten, D., Haddeland, I., Arnell, N. W., Clark, D. B., Dankers, R., Eisner, S., Fekete, B. M., ColónGonzález, F. J., Gossling, S. N., Kim, H., Liu, X., Masaki, Y., Portmann, F. T., Satoh, Y., Stacke, T., Tang, Q., Wada, Y., Wisser, D., Albrecht, T., Frieler, K., Piontek, F., Warszawski, L., and Kabat, P.: Multimodel assessment of water scarcity under climate change, P. Natl. Acad. Sci. USA, 111, 3245-3250, doi:10.1073/pnas.1222460110, 2014.

Schmidt, N., Lipp, E. K., Rose, J. B., and Luther, M. E.: ENSO Influences on Seasonal Rainfall and River Discharge in Florida, J. Climate, 14, 615-628, doi:10.1175/15200442(2001)014<0615:EIOSRA>2.0.CO;2, 2001.

Seneviratne, S. I., Koster, R. D., Guo, Z., Dirmeyer, P. A., Kowalczyk, E., Lawrence, D., Liu, P., Lu, C.-H., Mocko, D., Oleson, K. W., and Verseghy, D.: Soil moisture memory in AGCM simulations: Analysis of global land-atmosphere coupling experiment (GLACE) data, J. Hydrometeorol., 7, 1090-1112, doi:10.1175/JHM533.1, 2006.

Sharma, A.: Seasonal to interannual rainfall probabilistic forecasts for improved water supply management?: Part 3 - A nonparametric probabilistic forecast model, J. Hydrol., 239, 249-258, doi:10.1016/S0022-1694(00)00348-6, 2000.

Sheffield, J., Andreadis, K. M., Wood, E. F., and Lettenmaier, D. P.: Global and Continental Drought in the Second Half of the Twentieth Century: Severity-Area-Duration Analysis and Temporal Variability of Large-Scale Events, J. Climate, 22, 19621981, doi:10.1175/2008JCLI2722.1, 2008.

Smit, B. and Pilifosova, O.: From adaptation to adaptive capacity and vulnerability reduction, in: Climate Change, Adaptive Capacity and Development, edited by: Smith, J. B., Klein, R. J. T., and Huq, S., Imperial College Press, London, 2003.

Sperna Weiland, F. C., van Beek, L. P. H., Kwadijk, J. C. J., and Bierkens, M. F. P.: Global patterns of change in discharge regimes for 2100, Hydrol. Earth Syst. Sci., 16, 1047-1062, doi:10.5194/hess-16-1047-2012, 2012.

Stahl, K.: Hydrological Drought - a Study across Europe, PhD thesis, Freiburger Schriften zur hydrologie (No. 15), Institut fur Hydrologies, Universitat Freiburg, Freiburg, 2001.

Suarez, P., Hansen, J. W., Carriquiry, M., Mishra, A. K., and Osgood, D.: Integrating seasonal forecasts and insurance for adaptation among subsistence farmers: The case of Malawi (No. 4651), World Bank Policy Research Working Paper series, available at SSRN: http://ssrn.com/abstract=1149603 (last access: 5 May 2015), 2008.

van Beek, L. P. H., Wada, Y., and Bierkens, M. F. P.: Global monthly water stress: 1. Water balance and water availability, Water Resour. Res., 47, W07517, doi:10.1029/2010WR009791, 2011.

van Oldenborgh, G. J., Philip, S. Y., and Collins, M: El Niño in a changing climate: a multi-model study, Ocean Sci., 1, 81-95, doi:10.5194/os-1-81-2005, 2005.

Van Vliet, M. T. H., Franssen, W. H. P., Yearsley, J. R., Ludwig, F., Haddeland, I., Lettenmaier, D. P., and Kabat, P.: Global river discharge and water temperature under climate change, Global Environ. Chang., 23, 450-464, doi:10.1016/j.gloenvcha.2012.11.002, 2013.
Veldkamp, T. I. E., Wada, Y., de Moel, H., Kummu, M., Eisner, S., Aerts, J. C. J. H., and Ward, P. J.: Changing mechanism of global water scarcity events: Impacts of socioeconomic changes and inter-annual hydro-climatic variability, Global Environ. Chang., 32, 18-29, doi:10.1016/j.gloenvcha.2015.02.011, 2015.

Vicente-Serrano, S. M., Lopez-Moreno, J. I., Gimeno, L., Nieto, R., Moran-Tejeda, E., Lorenzo-Lacruz, J., Begueria, S., and Azorin-Molina, C.: A multiscalar global evaluation of the impacts of ENSO on droughts, J. Geophys. Res., 116, D20109, doi:10.1029/2011JD016039, 2011.

Vörösmarty, C. J., Green, P., Salisbury, J., and Lammers, R. B.: Global Water Resources: Vulnerability from Climate Change and Population Growth, Science, 289, 284-288, doi:10.1126/science.289.5477.284, 2000.

Wada, Y., van Beek, L. P. H., and Bierkens, M. F. P.: Modelling global water stress of the recent past: on the relative importance of trends in water demand and climate variability, Hydrol. Earth Syst. Sci., 15, 3785-3808, doi:10.5194/hess-15-37852011, 2011a.

Wada, Y., van Beek, L. P. H., Viviroli, D., Dürr, H. H., Weingartner, R., and Bierkens, M. F. P.: Global monthly water stress: 2. Water demand and severity of water stress, Water Resour. Res., 47, W07518, doi:10.1029/2010WR009792, 2011b.

Wada, Y., Gleeson, T., and Esnault, L.: Water wedges?: regional strategies to global water resource Wedge approach to water stress, Nat. Geosci., 7, 615-617, doi:10.1038/NGEO2241, 2014a.

Wada, Y., Wisser, D., and Bierkens, M. F. P.: Global modeling of withdrawal, allocation and consumptive use of surface water and groundwater resources, Earth Syst. Dynam., 5, 15-40, doi:10.5194/esd-5-15-2014, 2014b.

Wallace, J. M. and Hobbs, P.: Atmospheric Science, 2nd Edn., Academic Press, Burlington, USA, California, USA, London, UK, doi:10.1016/B978-0-12-732951-2.50002-8, p. 504, 2006. Multiple locations mentioned: Burlington, USA; California, USA; London, UK.

Wang, C., Xie, S., and Carton, J. A.: A Global Survey of Ocean - Atmosphere Interaction and Climate Variability, in: Earth Climate: The Ocean-Atmospheric Interaction, American Geophysical Union, Washington, DC, 1-19, doi:10.1029/147GM01, 2004.

Ward, P. J., Aerts, J. C. J. H., de Moel, H., and Renssen, H.: Verification of a coupled climate-hydrological model against Holocene palaeohydrological records, Global Planet, Change, 57, 283300, doi:10.1016/j.gloplacha.2006.12.002, 2007.

Ward, P. J., Beets, W., Bouwer, L. M., Aerts, J. C. J. H., and Renssen, H.: Sensitivity of river discharge to ENSO, Geophys. Res. Lett., 37, L12402, doi:10.1029/2010GL043215, 2010.

Ward, P. J., Eisner, S., Flörke, M., Dettinger, M. D., and Kummu, M.: Annual flood sensitivities to El Niño-Southern Oscillation at the global scale, Hydrol. Earth Syst. Sci., 18, 47-66, doi:10.5194/hess-18-47-2014, 2014a.

Ward, P. J., Jongman, B., Kummu, M., Dettinger, M. D., Sperna Weiland, F. C., and Winsemius, H. C.: Strong influence of El Nino Southern Oscillation on flood risk around the world, P. Natl. Acad. Sci. USA, 1-6, doi:10.1073/pnas.1409822111, 2014b.

Weedon, G. P., Gomes, S., Viterbo, P., Shuttleworth, W. J., Blyth, E., Österle, H., Adam, J. C., Bellouin, N., Boucher, O., and Best, M.: Creation of the watch forcing data and its use to assess global and regional reference crop evaporation over land 
during the twentieth century, J. Hydrometeorol., 12, 823-848, doi:10.1175/2011JHM1369.1, 2011.

Weedon, G. P., Balsamo, G., Bellouin, N., Gomes, S., Best, M. J., and Viterbo, P.: The WFDEI meteorological forcing data set: WATCH Forcing Data methodology applied to ERAInterim reanalysis data, Water Resour. Res., 50, 7505-7514, doi:10.1002/2014WR015638, 2014.

Whetton, P. H., Adamson, D. A., and Wilson, M. A. J.: Rainfall and river flow variability in Africa, Australia and East Asia linked to El Nino - Southern Oscillation events, in: Lessons for Human Survival: Nature's record from the Quaternary, edited by: Bishop, P., Geological Society of Australia Symposium Proceedings, 1, 71-82, 1990.

Wilks, D. S.: On "Field significance" and the false discovery rate, J. Appl. Meteorol. Clim., 45, 1181-1189, doi:10.1175/JAM2404.1, 2006.
Young, R. A.: Determining the economic value of water: Concepts and methods, Resources for the Future, Washington, DC, USA, p. 357, 2005

Zebiak, S. E., Orlove, B., Muñoz, Á. G., Vaughan, C., Hansen, J., Troy, T., Thomson, M. C., Lustig, A., and Garvin, S.: Investigating El Niño-Southern Oscillation and society relationships, Wiley Interdisciplinary Reviews: Climate Change, 6, 1734, doi:10.1002/wcc.294, 2014.

Zhang, Z., Chao, B. F., Chen, J., and Wilson, C. R.: Terrestrial water storage anomalies of Yangtze River Basin droughts observed by GRACE and connections with ENSO, Global Planet. Change, 126, 35-45, doi:10.1016/j.gloplacha.2015.01.002, 2015. 